\title{
JUSTIÇA E RECONHECIMENTO: ANÁLISE DO DIREITO À MORADIA À LUZ DAS TEORIAS DE AXEL HONNETH E NANCY FRASER
}

Daniel Queiroz Pereira ${ }^{1}$

\begin{abstract}
RESUMO
O termo "reconhecimento" se tornou recentemente uma palavra chave. Trata-se de uma categoria proveniente da filosofia de Hegel que foi novamente utilizada por teóricos políticos como forma de definir os conflitos decorrentes de questões relacionadas a identidade e diferença. Isto posto, o objetivo precípuo do presente trabalho reside em apontar os principais pontos concernentes às teorias de Axel Honneth e Nancy Fraser sobre o tema, relacionando as questões referentes ao reconhecimento (e à distribuição) aos fenômenos que atualmente são facilmente identificados, sobretudo, nos centros urbanos: a existência de diferentes classes e "status" e a necessidade da superação dos paradigmas que culminaram nessa situação como forma de se efetivar e promover o direito à moradia. Busca-se, pois, através da análise das teorias de Honneth e Fraser, tornar os indivíduos relegados às "cidades informais", caracterizadas pelas áreas onde se localizam as favelas e loteamentos populares irregulares, verdadeiros partícipes via reconhecimento.
\end{abstract}

Palavras-chave: Justiça. Reconhecimento..(re)distribuição. Participação. Direito à Moradia.

\section{JUSTICE AND RECOGNITION: ANALYSIS OF THE RIGHT TO SHELTER IN THE PERSPECTIVE OF AXEL HONNETH AND NANCY FRASER'S THEORIES.}

\begin{abstract}
The term "recognition" became recently a key-word. It is a category originated in Hegel's philosophy that was once more used by theoretical politics as a way to define the conflicts that came from problems related to identity and difference. So far, the main objective of the present work lies in indicating the principal aspects related to Axel Honneth and Nancy Fraser's theories about this issue, establishing a connection

\footnotetext{
${ }^{1}$ Advogado. Professor Assistente de Legislação Social da Universidade Federal do Estado do Rio de Janeiro - UNIRIO. Assistente de pesquisas da Editora Atlas S.A. Bacharel, Mestre e Doutorando em Direito da Cidade pela Universidade do Estado do Rio de Janeiro - UERJ. Pós-graduado em Direito Material e Processual do Trabalho pela Universidade Gama Filho - UGF. Ex-coordenador, juntamente com o Professor Guilherme Calmon Nogueira da Gama, do Grupo de Pesquisa Institucional em Direito Civil-Constitucional da Universidade do Estado do Rio de Janeiro - UERJ e Ex-Professor substituto de Direito Penal Econômico, Direito Econômico e História do Direito Brasileiro da Universidade do Estado do Rio de Janeiro - UERJ. Ex-Coordenador Editorial da Revista de Direito da Cidade: Revista dos PósGraduandos em Direito da Universidade do Estado do Rio de Janeiro
} 
between recognition (and distribution) and the phenomena that can be easily identified, specially in the urban centers: the existence of different classes and "status" and the need of surpassing the paradigms that lead to this situation as a way of putting into effect and promoting the right to shelter. Therefore, this work seeks, throughout the analysis of Honneth and Fraser's theories, to turn the individuals that live in "informal cities", characterized by slums and irregular popular allotments, true participants through recognition.

\author{
Keywords: Justice. Recognition. (re)distribution. Participation. Right to \\ Shelter
}

\title{
1. Introdução
}

O termo "reconhecimento" se tornou recentemente uma palavra chave. Trata-se de uma categoria proveniente da filosofia de Hegel que foi ressuscitada por teóricos políticos como forma de conceituar os conflitos decorrentes de questões relacionadas a identidade e diferença ${ }^{2}$.

Neste particular, o objetivo precípuo do presente trabalho reside em apontar os principais pontos relativos às concepções de Axel Honneth e Nancy Fraser sobre o tema, bem como relacionar as questões referentes ao reconhecimento (e à distribuição) aos fenômenos que atualmente são facilmente identificados, sobretudo, nos centros urbanos: a existência de diferentes classes e "status" e a necessidade da superação dos paradigmas que culminaram nessa situação como forma de se efetivar e promover o direito à moradia.

Contudo, neste primeiro momento é imperiosa a definição de algumas premissas.

A primeira delas reside no fato de que a cultura metropolitana é, em todo lugar, um espaço de formas híbridas, um produto de trocas e empréstimos no que concerne a tempo e espaço. Por outro lado, instala-se um processo de monopólio metropolitano, isto é, dá-se a marca da autenticidade e de valor ao estilo de vida que emana da

\footnotetext{
${ }^{2}$ Como forma de demonstrar a atualidade do tema, é alvissareira a transcrição do seguinte fragmento: "whether the issue is indigenous land claims or women's carework, homosexual marriage or Muslin headscarves, moral philosophers increasingly use the term 'recognition' to unpack the normative bases of political claims. They find that a category that conditions subjects' autonomy or intersubjective regard well captures the moral stakes of many contemporary conflicts. And no wonder. Hegel's old figure of 'the struggle for recognition' finds new purchase as a rapidly globalizing capitalism accelerates transcultural contacts, fracturing value horizons, and politicizing identities and differences". FRASER, Nancy e HONNETH, Axel. "Introduction: Redistribution or recognition" in FRASER, Nancy e HONNETH, Axel (trad. Joel Gob, James Ingram e Christiane Wilke). Redistribution or Recognition? - A politicalphilosophical exchange. New York e London: Verso, 2003, p. 01.
} 
metrópole. Além disso, faz-se com que cada afastamento do padrão metropolitano institucionalizado pareça deploravelmente provinciano, rude e desatualizado ${ }^{3}$. Neste ponto, Ayse Öncü e Petra Weyland afirmam que

inherent to the concept of global flows, differentiated and differentiating, is the capacity to transgress taken-for-granted boundaries between nationstates, between racial, ethnic and gender groups, between public and private spheres ${ }^{4} .[\ldots]$ Feminist, gay, environmentalist, anti-nuclear, pronatalist, and so on, movements have been among the most frequently cited examples of such flexi-identities and neo-tribes ${ }^{5}$.

Deste modo, a existência de diferentes grupos suscita, como já se mencionou, questões atinentes ao reconhecimento, que acabam por manifestar repercussões sobre o direito de propriedade e, conseqüentemente, de moradia, bem como sobre os mecanismos que buscam promovê-los, tais como a regularização fundiária, sobretudo instrumentalizada através de mecanismos como a usucapião especial coletiva e a concessão do direito real de uso.

Aqui, cumpre mencionar que o direito de propriedade nem é pleno, nem é benesse atribuída pelo Estado. Ele é algo construído dia-a-dia pela participação dos homens, com sua ação concreta sobre um bem fisicamente identificável e num contexto social, assumindo diferentes dimensões e conotações, conforme a época considerada ${ }^{6}$. O Estado como instrumento de ação da coletividade, sendo esta formada pela reunião de indivíduos portadores de características próprias e dignidade humana a ser respeitada, deve prezar pelo atendimento das necessidades desses indivíduos, inclusive no que se refere à moradia.

\footnotetext{
${ }^{3}$ Fazendo alusão ao aspecto econômico desse processo, afirma Lewis Mumford que "a meta final desse processo seria uma população unificada, homogênea, completamente padronizada, cortada segundo o molde metropolitano e condicionada a consumir apenas aqueles produtos que são oferecidos pelos controladores e condicionadores, no interesse de uma economia em contínua expansão. Em países como os Estados Unidos, onde esse fenômeno se tem verificado de maneira mais rápida, aquela meta já se acha claramente à vista. [...] $O$ controle sem a realeza: a conformidade sem a escolha: o poder sem a intervenção da personalidade”. MUMFORD, Lewis (trad. Neil R. da Silva). A Cidade na História: suas origens, transformações e perspectivas. 4 ed. São Paulo: Martins Fontes, 1998, p. 580.
}

${ }^{4}$ ÖNCÜ, Ayse e WEYLAND, Petra. "Introduction: struggles over lebensraum and social identity in globalizing cities" in ÖNCÜ, Ayse e WEYLAND, Petra. Space, Culture, and Power: new identities in globalizing cities. London e New Jersey: Zed Books, 1997, pp. 03-04.

${ }^{5}$ ÖNCÜ, Ayse e WEYLAND, Petra. "Introduction: struggles over lebensraum and social identity in globalizing cities" in ÖNCÜ, Ayse e WEYLAND, Petra. Space, Culture, and Power: new identities in globalizing cities. London e New Jersey: Zed Books, 1997, p. 09.

${ }^{6}$ GRECO, Marco Aurélio. "O Solo Criado e a Questão Fundiária” in PESSOA, Álvaro (coord.). Direito do Urbanismo: uma visão sócio-jurídica. Rio de Janeiro: Livros Técnicos e Científicos: Instituto Brasileiro de Administração Municipal, 1981, p. 04. 
Neste ponto, as cidades informais caracterizadas pelas áreas onde se localizam as favelas, os loteamentos populares irregulares e clandestinos nas periferias urbanas, nas áreas declaradas de proteção ambiental, as ocupações coletivas de área urbana, conjuntos habitacionais em condições precárias ou abandonados, os cortiços e habitações nas regiões centrais da cidade, são situações concretas que evidenciam a necessidade de construir uma política urbana que contém um novo marco legal para as cidades, com o objetivo de promover a integração social e territorial da população que vive nesses assentamentos urbanos ${ }^{7}$. A ordem legal urbana, ao revés, é formada por um conjunto de legislações contendo padrões urbanísticos de parcelamento, de uso, de ocupação e de edificação do solo urbano elitista que atendem aos interesses da parcela da população que tem renda na cidade. Esses padrões historicamente têm sido definidos visando aos interesses do mercado imobiliário, que define as áreas nas cidades que devem ter um padrão elevado ou razoável de qualidade de vida ambiental e urbano (oferta de infra-estrutura, equipamentos e serviços), gerando a valorização imobiliária destas áreas em razão dos investimentos públicos realizados, bem como para proteger os interesses da população dos bairros que contêm um padrão de qualidade de vida ambiental urbana razoável ou elevado ${ }^{8}$.

O desafio reside, portanto, em tornar os indivíduos relegados a tais áreas verdadeiros partícipes via reconhecimento. Daí a importância de se lançar um cuidadoso olhar sobre as teorias de Honneth e Fraser.

\section{A "luta por reconhecimento" e a perspectiva de Axel Honneth}

\subsection{O ponto de partida}

Axel Honneth busca construir uma teoria da sociedade a partir da observância do princípio no qual o pragmatista Mead coincidiria fundamentalmente com o primeiro Hegel. Nesta acepção, a reprodução da vida social se efetua sob o imperativo de um reconhecimento recíproco, uma vez que os sujeitos só podem chegar a uma auto-relação prática quando aprendem a se conceber, da perspectiva normativa de seus parceiros de

\footnotetext{
7 SAULE JÚNIOR, Nelson. "Formas de Proteção do Direito à Moradia e de Combate aos Despejos Forçados no Brasil" in FERNANDES, Edésio. Direito Urbanístico e Política Urbana no Brasil. Belo Horizonte: Del Rey, 2000, pp. 101-102.

${ }^{8}$ SAULE JÚNIOR, Nelson. "Formas de Proteção do Direito à Moradia e de Combate aos Despejos Forçados no Brasil" in FERNANDES, Edésio. Direito Urbanístico e Política Urbana no Brasil. Belo Horizonte: Del Rey, 2000, p. 112.
} 
interação, como seus destinatários sociais. Neste ponto, a concepção de Mead confere à teoria hegeliana da "luta por reconhecimento" um viés "materialista" .

Contudo, afirma Honneth que uma teoria alicerçada em tal ideário só pode sustentar-se caso seja remetida de forma sistemática a processos no interior da práxis da vida social, isto é, "são as lutas moralmente motivadas de grupos sociais, sua tentativa coletiva de estabelecer institucional e culturalmente formas ampliadas de reconhecimento recíproco, aquilo que por meio do qual vem a se realizar a transformação normativamente gerida das sociedades ${ }^{10}$. Tal teoria do reconhecimento - desenvolvida por Mead e Hegel, ainda que sob prismas distintos - conferiu à luta social uma interpretação na qual ela pôde se tornar uma força estruturante na evolução moral da sociedade.

Antes de aprofundar a referida teoria da sociedade, busca Honneth expor de forma sistemática os pressupostos que se encontram inscritos nas teorias de Hegel e Mead.

Assim sendo, o primeiro ponto a ser aqui abordado diz respeito à tripartição que ambos os autores parecem realizar nas formas de reconhecimento recíproco. Para ilustrar tal concepção verifica-se alvissareiro reproduzir a distinção feita por Mead. Segundo Mead, as formas de reconhecimento recíproco são: da dedicação emotiva, como se pode vislumbrar nas relações amorosas e nas amizades, o reconhecimento jurídico e o assentimento solidário. Em Hegel são atribuídos a esses padrões de reciprocidade conceitos especiais de pessoa, de forma que a autonomia subjetiva do indivíduo aumenta também com cada etapa de respeito recíproco. Ocorre que, apenas em Mead, tem-se a construção de uma versão sistemática de uma hipótese empírica,

\footnotetext{
${ }^{9}$ Cumpre ainda mencionar que "não foi somente a premissa geral do primeiro Hegel, segundo a qual a formação prática da identidade humana pressupõe a experiência do reconhecimento intersubjetivo, que reapareceu em Mead na forma alterada de uma hipótese empírica de pesquisa; também foi possível encontrar em sua obra os equivalentes teóricos; oriundos de uma concepção pós-metafísica e naturalista, para a distinção conceitual de diversas etapas de reconhecimento, e mesmo para a firmação, de longo alcance, acerca de uma luta que medeia essas etapas. Portanto, com a inclusão da psicologia social de Mead, a idéia que o jovem Hegel traçou em seus escritos de Jena com rudimentos geniais pode se tornar o fio condutor de uma teoria social de teor normativo; seu propósito é esclarecer os processos de mudança social reportando-se às pretensões normativas estruturalmente inscritas na relação de reconhecimento recíproco". HONNETH, Axel. "Padrões de reconhecimento intersubjetivo: amor, direito, solidariedade" in HONNETH, Axel (trad. Luiz Repa). A Luta por Reconhecimento - A gramática moral dos conflitos sociais. São Paulo: Editora 34, 2003, p. 155.

10 HONNETH, Axel. "Padrões de reconhecimento intersubjetivo: amor, direito, solidariedade" in HONNETH, Axel (trad. Luiz Repa). A Luta por Reconhecimento - A gramática moral dos conflitos sociais. São Paulo: Editora 34, 2003, p. 156.
} 
segundo a qual o grau de relação positiva da pessoa consigo mesma se intensifica passo a passo na sequiência das três formas de reconhecimento ${ }^{11}$.

Coincidem ainda os dois autores na tentativa de localizar os diversos modos de reconhecimento nas respectivas esferas de reprodução social. Hegel distingue em sua filosofia política a família, a sociedade civil e o Estado. Já Mead destaca as relações primárias do outro concreto as relações jurídicas e a esfera do trabalho.

Salienta ainda Honneth que outros representantes da filosofia social também adotam a sistemática inscrita nessas diferentes tripartições. Neste particular, cita a posição de Max Scheler que distingue com "comunidade de vida", "sociedade" e "comunidade de pessoas" (fundada em solidariedade), três "formas essenciais da unidade social", que também podem ser postas em paralelo com etapas de desdobramento do ser da pessoa. Já Plessner, aqui ambamente referido pelo autor, propõe uma distinção, com vista aos diversos graus de confiança intersubjetiva, em três esferas de ligações primárias, de relacionamento social e de comunidade objetiva.

Ocorre que esta visão, no plano da história teórica, dificilmente pode provar mais que a grande plausibilidade de uma subdivisão da vida social em três esferas de interação, sendo manifestamente óbvio distinguir formas de integração social conforme ela se realize pela via das ligações emotivas, da adjudicação de direitos ou da orientação comum de valores.

Neste ponto, afirma Honneth que para poder examinar essas pretensões amplas, busca-se reconstruir o conteúdo concretamente dado do amor, do direito e da solidariedade.

\subsection{Os padrões de reconhecimento intersubjetivo}

\footnotetext{
11 "Hegel efetuou esse passo, desenvolvendo a teoria do reconhecimento até chegar a um modelo de conflito, de maneira idealista; Mead o fez de uma maneira que já se pode dizer 'materialista'; em contraposição à tradição teórica que vai de Maquiavel até Nietzsche, passando por Hobbes, os dois pensadores deram à luta social uma interpretação na qual ela pôde se tornar uma força estruturante na evolução moral da sociedade". HONNETH, Axel. "Padrões de reconhecimento intersubjetivo: amor, direito, solidariedade" in HONNETH, Axel (trad. Luiz Repa). A Luta por Reconhecimento - A gramática moral dos conflitos sociais. São Paulo: Editora 34, 2003, p. 156. É relevante ainda salientar que "tanto em Hegel quanto em Mead não se encontra uma consideração sistemática daquelas formas de desrespeito que podem tornar experienciável para os atores sociais, na qualidade de um equivalente negativo das correspondentes relações de reconhecimento, o fato de reconhecimento denegado", tema este que Honneth buscou explorar, como se verá adiante. HONNETH, Axel. "Padrões de reconhecimento intersubjetivo: amor, direito, solidariedade" in HONNETH, Axel (trad. Luiz Repa). A Luta por Reconhecimento - A gramática moral dos conflitos sociais. São Paulo: Editora 34, 2003, p. 157.
} 
O primeiro padrão de relação apontado por Honneth reside no amor. Por relações amorosas devem ser entendidas todas as relações primárias, na medida em que elas consistam em ligações emotivas fortes entre poucas pessoas.

Neste particular, Honneth suscita o posicionamento de Hegel, para quem o "amor" designa mais do que somente o relacionamento sexualmente preenchido entre homem e mulher, aplicando-se o referido conceito também ao relacionamento afetivo entre pais e filhos no interior da família, por exemplo.

Para Hegel, o amor representa a primeira etapa de reconhecimento recíproco, porque em sua efetivação os sujeitos se confirmam mutuamente na natureza concreta de suas carências, reconhecendo-se assim como seres carentes ${ }^{12}$.

Nesta perspectiva, carências e afetos só podem de certo modo receber "confirmação" porque são diretamente satisfeitos ou correspondidos. Deve, portanto, o reconhecimento possuir aqui o caráter de assentimento e encorajamento afetivo, estando essa relação de reconhecimento também ligada de maneira necessária à existência corporal dos outros concretos, os quais demonstram entre si sentimentos de estima especial.

Dessa forma, o amor tem de ser concebido como um "ser-si-mesmo em um outro". As relações primárias afetivas dependem de um equilíbrio precário entre autonomia e ligação, o qual constitui o interesse diretivo pela determinação das causas de desvios patológicos na teoria psicanalítica das relações de objeto.

Todavia, não é a ampliação intersubjetiva do quadro explicativo psicanalítico como tal o que faz a teoria das relações de objeto parecer especialmente apropriada para os fins de uma fenomenologia das relações de reconhecimento, já que ela só permite uma ilustração do amor como uma forma determinada de reconhecimento em virtude do modo específico pelo qual o sucesso das ligações afetivas se torna dependente da capacidade, adquirida na primeira infância, para o equilíbrio entre a simbiose e a autoafirmação $^{13}$.

\footnotetext{
${ }^{12}$ Nas palavras de Honneth, "na experiência recíproca da dedicação amorosa, dois sujeitos se sabem unidos no fato de serem dependentes, em seu estado carencial, do respectivo outro". HONNETH, Axel. "Padrões de reconhecimento intersubjetivo: amor, direito, solidariedade" in HONNETH, Axel (trad. Luiz Repa). A Luta por Reconhecimento - A gramática moral dos conflitos sociais. São Paulo: Editora 34, 2003, p. 160.

${ }^{13}$ A partir dessa abordagem psicanalítica, "a ligação afetiva com outras pessoas passa a ser investigada como um processo cujo êxito depende da preservação recíproca de uma tensão entre o auto-abandono simbiótico e a auto-afirmação individual". HONNETH, Axel. "Padrões de reconhecimento intersubjetivo: amor, direito, solidariedade" in HONNETH, Axel (trad. Luiz Repa). A Luta por Reconhecimento - A gramática moral dos conflitos sociais. São Paulo: Editora 34, 2003, p. 160.
} 
Essa idéia central surgiu a partir dos estudos do psicanalista inglês Donald W. Winnicott e foi aprofundada por Jessica Benjamin que, reportando-se aos escritos de Winnicott, empreendeu uma primeira tentativa de interpretar, com os meios psicanalíticos, a relação amorosa como um processo de reconhecimento recíproco ${ }^{14}$.

Sob este prisma, em seus primeiros meses de vida, a criança pequena depende a tal ponto da complementação prática de seu comportamento pelos cuidados maternos que ela representa uma abstração errônea quando a pesquisa psicanalítica a considera um objeto de investigação independente, isolada de qualquer pessoa de referência estado do ser-um simbiótico.

Nesta fase, mãe e a criança dependem uma da outra e, por isso, a referida unidade simbiótica só pode chegar a um termo quando ambas obtêm para si um pouco de independência. Trata-se da "des-adaptação graduada". Aqui Winnicott anexa o conceito de "dependência relativa", que constitui-se na relação entre mãe e filho aquele "ser si-mesmo em um outro", o qual pode ser concebido como padrão elementar de todas as formas maduras de amor ${ }^{15}$.

A partir desse momento, a mãe passa a ser vivenciada pela primeira vez como algo no mundo que não está sob o controle da própria onipotência. Isso significa para a criança uma percepção germinal de sua dependência, uma vez que ela sai da fase da "absoluta de pendência" porque a própria dependência em relação à mãe entra em seu campo de visão. Disso resulta para a criança um processo de desilusão e o bebê desenvolve uma disposição para atos agressivos, primariamente dirigidos à mãe. Contudo, percebe-se que se a mãe souber passar pelo teste de seu filho, tolerando os ataques agressivos, típicos dessa fase de "des-adaptação graduada", sem a vingança de privá-lo do amor, então, da perspectiva dele, ela passa a pertencer a um mundo exterior

\footnotetext{
${ }^{14}$ De fato, com a abertura da psicanálise à pesquisa, como a que se verificou na Inglaterra e nos Estados Unidos da América, gerou-se um efeito estimulante de larga medida que apontou, em oposição ao modelo estrutural do Id e do Ego oriundo da teoria freudiana, para a importância duradoura das experiências interativas primevas e pré-lingüísticas. HONNETH, Axel. "Padrões de reconhecimento intersubjetivo: amor, direito, solidariedade" in HONNETH, Axel (trad. Luiz Repa). A Luta por Reconhecimento - A gramática moral dos conflitos sociais. São Paulo: Editora 34, 2003, p. 162.

15 “A essa 'des-adaptação graduada' da mãe corresponde, pelo lado do bebê, um desenvolvimento intelectual que provoca, juntamente com a ampliação dos reflexos condicionados, a capacidade de diferenciar cognitivamente o próprio ego e o ambiente: na idade média de seis meses, ele começa a entender sinais acústicos ou ópticos como índices de futuras satisfações de carências, de sorte que pode suportar progressivamente a ausência da mãe em curtos períodos". HONNETH, Axel. "Padrões de reconhecimento intersubjetivo: amor, direito, solidariedade" in HONNETH, Axel (trad. Luiz Repa). A Luta por Reconhecimento - A gramática moral dos conflitos sociais. São Paulo: Editora 34, 2003, p. 167.
} 
aceito com dor. Pela primeira vez, ele terá de tomar consciência agora de sua dependência em relação à dedicação dela. Se o amor da mãe é duradouro e confiável, a criança é capaz de desenvolver ao mesmo tempo, à sombra de sua confiabilidade intersubjetiva, uma confiança na satisfação social de suas próprias demandas ditadas pela carência; pelas vias psíquicas abertas dessa forma, vai se desdobrando nela, de maneira gradual, uma "capacidade elementar de estar só". Neste momento, a criança começa a descobrir de maneira descontraída "sua própria vida pessoal". Na medida em que "há um bom objeto na realidade psíquica do indivíduo" ele pode se entregar a seus impulsos internos, sem o medo de ser abandonado, buscando entendê-los de um modo criativo e aberto à experiência. Desenvolvem-se, deste modo, discernimentos profundos acerca do nexo de criatividade e reconhecimento ${ }^{16}$.

Neste sentido, salienta Honneth que a "capacidade de estar só" é a expressão prática de uma forma de auto-relação individual. Apenas a quebra da simbiose faz surgir aquela balança produtiva entre delimitação e deslimitação, que, para Winnicott, pertence à estrutura de uma relação amorosa amadurecida pela desilusão mútua. Nesse ponto, o poder-estar-só constitui o pólo, relativo ao sujeito, de uma tensão intersubjetiva, cujo pólo oposto é a capacidade de fusão deslimitadora om o outro ${ }^{17}$.

\footnotetext{
${ }^{16}$ Faz-se imperioso ressaltar que o trilhar desse caminho passa também pela contração, por parte da criança, de uma relação afetivamente investida com objetos de seu ambiente material. É o que se convencionou denominar de "objeto transicional". Nesse particular, "a função dos objetos transicionais não pode limitar-se a assumir simbioticamente o papel da mãe vivenciada no estado de fusão; a criança não somente se refere aos objetos escolhidos por ela com ternura simbiótica, mas também os expõe repetidas vezes a ataques furiosos e a tentativas de destruição. Winnicott crê poder concluir daí que os objetos transicionais seriam de certo modo elos de mediação ontológica entre a vivência primária do estar fundido e a experiência do estar separado". HONNETH, Axel. "Padrões de reconhecimento intersubjetivo: amor, direito, solidariedade" in HONNETH, Axel (trad. Luiz Repa). A Luta por Reconhecimento - A gramática moral dos conflitos sociais. São Paulo: Editora 34, 2003, p. 171.
}

${ }^{17} \mathrm{O}$ ato de deslimitação recíproca, no qual os sujeitos se experienciam como reconciliados uns com os outros, pode assumir, segundo a espécie de ligação, as formas mais diversas: nas amizades, pode ser a experiência comum de um diálogo que nos absorve ou o estar-junto inteiramente espontâneo; nas relações eróticas, é a união sexual, pela qual um se sabe reconciliado com o outro, sem diferenças. Em cada caso, porém, o processo de fusão tira a condição de sua possibilidade em geral somente da experiência oposta do outro, sempre se contornando novamente em seus limites; somente porque a pessoa amada readquire, dada a segurança da dedicação, a força de abrir-se para si mesma na relação descontraída consigo, ela se torna o sujeito autônomo com que o ser-um pode ser vivenciado como uma deslimitação mútua. Nesse aspecto, a forma de reconhecimento do amor, que Hegel havia descrito como um "ser-si mesmo em um outro", não designa um estado intersubjetivo, mas um arco de tensões comunicativas que medeiam continuamente a experiência do poder-estar-só com a do estar-fundido; a "referencialidade do eu" e a simbiose representam aí os contrapesos mutuamente exigidos que, tomados em conjunto, possibilitam um recíproco estar-consigo-mesmo no outro. HONNETH, Axel. "Padrões de reconhecimento intersubjetivo: amor, direito, solidariedade" in HONNETH, Axel (trad. Luiz Repa). A Luta por Reconhecimento - A gramática moral dos conflitos sociais. São Paulo: Editora 34, 2003, p. 175. 
Se o amor representa uma simbiose quebrada pela individuação recíproca, então o que nele encontra reconhecimento junto ao respectivo outro é manifestamente apenas sua independência individual.

Desta forma, toda relação amorosa, seja aquela entre pais e filhos, a amizade ou o contato íntimo, está ligada, por isto, à condição de simpatia e atração, o que não está à disposição do indivíduo.

Dando continuidade a sua teoria, Honneth reproduz fragmento da lavra de Hegel, em que assevera:

no Estado, [...] o homem é reconhecido e tratado como ser racional, como livre, como pessoa; e o singular, por sua parte, se torna digno desse reconhecimento porque ele, com a superação da naturalidade de sua autoconsciência, obedece a um universal, à vontade sendo em si e para si, à lei, ou seja, se porta em relação aos outros de uma maneira universalmente válida, reconhece-os como o que ele próprio quer valer como livre, como pessoa ${ }^{18}$.

Constata-se que a formulação ora enfocada, empregando o predicado "livre", torna evidente que Hegel, com a forma de reconhecimento do direito, visa desde o início à constituição específica das relações jurídicas.

Mead, nesse particular, remete à circunstância elementar de todo sujeito humano poder ser considerado portador de alguns direitos, quando reconhecido socialmente como membro de uma coletividade.

Ainda no que concerne à estrutura da qual Hegel pode derivar suas determinações da pessoa de direito, cumpre mencionar que a mesma só assume a forma de reconhecimento do direito quando ela se torna dependente historicamente das premissas dos princípios morais universalistas. Pois, com a passagem para a modernidade, as categorias pós-convencionais, que já antes foram desenvolvidas na filosofia e na teoria política, penetram no direito em vigor, submetendo-o às pressões de fundamentação associadas à idéia de um acordo racional acerca de normas controversas; o sistema jurídico precisa ser entendido de agora em diante como expressão dos interesses universalizáveis de todos os membros da sociedade, de sorte que ele não admitia mais, segundo sua pretensão, exceções e privilégios. Deste modo, uma disposição para a obediência de normas jurídicas só pode ser esperada dos parceiros de interação quando eles puderam assentir a elas, em princípio, como seres livres e iguais, migra para a relação de reconhecimento do direito uma forma de reciprocidade,

${ }^{18}$ HONNETH, Axel. "Padrões de reconhecimento intersubjetivo: amor, direito, solidariedade" in HONNETH, Axel (trad. Luiz Repa). A Luta por Reconhecimento - A gramática moral dos conflitos sociais. São Paulo: Editora 34, 2003, p. 179. 
altamente exigente: obedecendo à mesma lei, os sujeitos de direito se reconhecem reciprocamente como pessoas capazes de decidir com autonomia individual sobre normas morais.

Isto posto, pode-se perceber que, diferentemente das definições de Mead, as de Hegel só valem para a ordem social do direito na medida em que esta pôde se desligar da autoridade natural de tradições éticas, adaptando-se ao princípio de fundamentação universalista.

A partir dessa distinção destaca Honneth o surgimento de duas questões:

1) Por um lado, é preciso deixar claro que caráter deve demonstrar uma forma de reconhecimento que realça em todos os outros membros da comunidade jurídica a mesma propriedade de autonomia individual; já se aprendeu de Hegel que um tal tipo de respeito universalista não deve ser mais concebido como uma atitude ligada às emoções, mas somente como uma operação de entendimento puramente cognitiva, que coloca barreiras quase internas às sensações afetivas; nesse sentido, será preciso explicar como se constitui um tipo de respeito que, se de uma parte deve ter-se desligado dos sentimentos de simpatia e afeição, de outra tem de poder dirigir, porém, o comportamento individual;

2) Por outro lado, é preciso responder à questão sobre o que pode significar que os sujeitos se reconheçam reciprocamente em sua imputabilidade moral, sob as condições das relações jurídicas modernas; uma tal propriedade, que todos os sujeitos devam partilhar, não pode estar referida a capacidades humanas definidas, de uma vez por todas, em sua extensão ou em seu conteúdo; pelo contrário, mostrar-se-á que resulta da indeterminidade fundamental do que constitui o status de uma pessoa imputável uma abertura estrutural do direito moderno para ampliações e precisões gradativas.

Conclui ainda o autor que, se com a passagem para a modernidade os direitos individuais se desligam das expectativas concretas específicas dos papéis sociais, já que competem, em igual medida, a todo homem na qualidade de ser livre, no âmbito das relações jurídicas ligadas às tradições, é possível afirmar que o reconhecimento como pessoa de direito ainda está fundido aqui, de certo modo, com a estima social que se aplica ao membro individual da sociedade em seu status social: a eticidade convencional de semelhantes coletividades constitui um horizonte normativo em que a multiplicidade de direitos e deveres individuais continua vinculada às tarefas, distintamente avaliadas, no interior da estrutura social de cooperação. 
Tal nexo só se dissolve na seqüência do processo histórico que submete as relações jurídicas às exigências de uma moral pós-convencional; desde então, o reconhecimento como pessoa de direito, que, conforme sua idéia, deve se aplicar a todo sujeito na mesma medida, aparta-se a tal ponto do grau de estima social, que acabam originando duas formas distintas de respeito. Para elucidá-las Honneth recorre a Ihering que afirma que a referida bipartição decorre das distintas possibilidades de responder à questão sobre o que pode ser respeitado em um outro ser humano:

no 'reconhecimento jurídico', como ele também já diz em seu texto, se expressa que todo ser humano deve ser considerado, sem distinção, um 'fim em si', ao passo que o 'respeito social' salienta o 'valor' de um indivíduo, na medida em que este se mede intersubjetivamente pelos critérios da relevância social ${ }^{19}$.

No primeiro caso, há, portanto, a necessidade de lidar com um respeito universal pela "liberdade da vontade da pessoa"; no segundo caso, ao contrário, com o reconhecimento de realizações individuais, cujo valor se mede pelo grau em que são conhecidos por uma sociedade como relevantes.

Contudo, esclarece Honneth que apenas quando se acrescenta à interpretação da situação um saber prático sobre as limitações que se tem de impor às ações de uma pessoa perante outra, a consideração cognitiva vem a ser o respeito moral a que o conceito se referiu desde Kant. Reconhecer todo outro ser humano como uma pessoa significa, então, agir em relação a ele do modo a que nos obrigam moralmente as propriedades de uma pessoa.

Desta forma, na estrutura do reconhecimento jurídico encerram-se duas operações da consciência. A primeira pressupõe um saber moral sobre as obrigações jurídicas que temos de observar perante pessoas autônomas. Já a segunda reside na constatação de que só uma interpretação empírica da situação permite definir, quanto a um defrontante concreto, se se trata de um ser com a propriedade que faz aplicar aquelas obrigações.

Percebe-se, pois, que um direito universalmente válido deve ser questionado, à luz das descrições empíricas da situação, no sentido de saber a que círculo de sujeitos ele deve se aplicar, visto que eles pertencem à classe das pessoas moralmente imputáveis.

\footnotetext{
19 HONNETH, Axel. "Padrões de reconhecimento intersubjetivo: amor, direito, solidariedade" in HONNETH, Axel (trad. Luiz Repa). A Luta por Reconhecimento - A gramática moral dos conflitos sociais. São Paulo: Editora 34, 2003, p. 184.
} 
Assim sendo, a capacidade que justifica a proteção dos sujeitos juridicamente capazes e que permite à ordem jurídica contar com a disposição individual para a obediência reside no assentimento livre de todos os indivíduos inclusos na referida ordem. Logo, é preciso supor nesses sujeitos de direito a capacidade de decidir racionalmente, com autonomia individual, sobre questões morais; sem uma semelhante atribuição, não seria absolutamente imaginável como os sujeitos devem ter podido alguma vez acordar reciprocamente acerca de uma ordem jurídica. Nesse sentido, toda comunidade jurídica moderna, unicamente porque sua legitimidade se torna dependente da idéia de um acordo racional entre indivíduos em pé de igualdade, está fundada na assunção da imputabilidade moral de todos os seus membros.

A definição das propriedades que caracterizam o ser humano constitutivamente como pessoa depende, pois, das assunções de fundo acerca dos pressupostos subjetivos que capacitam para a participação numa formação racional da vontade: quanto mais exigente é a maneira pela qual se pensa um semelhante procedimento, tanto mais abrangentes devem ser as propriedades que, tomadas em conjunto, constituem a imputabilidade moral de um sujeito.

Nas ciências do direito, tornou-se natural nesse meio efetuar uma distinção dos direitos subjetivos em direitos liberais de liberdade, direitos políticos de participação e direitos sociais de bem-estar; a primeira categoria refere-se aos direitos negativos que protegem a pessoa de intervenções desautorizadas do Estado, com vista à sua liberdade, sua vida e sua propriedade; a segunda categoria, aos direitos positivos que lhe cabem com vista à participação em processos de formação pública da vontade; e a terceira categoria, finalmente, àqueles direitos igualmente positivos que a fazem ter parte, de modo eqüitativo, na distribuição de bens básicos.

Ainda nesta perspectiva, expõe Honneth a tentativa de T.H. Marshall de reconstruir o nivelamento histórico das diferenças sociais de classe como um processo gerido de ampliação de direitos individuais fundamentais. Marshall, ao seu turno, sistematiza o conjunto de todas as pretensões jurídicas em uma composição tripartite com viés histórico. Segundo o autor, a constituição dos direitos liberais de liberdade deu-se no século XVIII, o estabelecimento dos direitos políticos de participação, no XIX, e finalmente a criação de direitos sociais de bem-estar, no XX; no entanto, em sua sugestiva periodização é importante para os fins aqui colimados somente a demonstração de que a imposição de cada nova classe de direitos fundamentais foi 
sempre forçada historicamente com argumentos referidos de maneira implícita à exigência de ser membro com igual valor da coletividade política ${ }^{20}$.

Tal digressão é relevante, pois permite a constatação de que um sujeito é respeitado se encontra reconhecimento jurídico não só na capacidade abstrata de poder orientar-se por normas morais, mas também na propriedade concreta de merecer o nível de vida necessário para isso.

Outro aspecto suscitado por Honneth consiste na menção ao conceito de autorespeito. Esta decorre do experimento mental que Joel Feinberg desenvolveu, a fim de demonstrar o valor moral da adjudicação de direitos. Para Feinberg, há um inegável nexo (ainda que conceitual ${ }^{21}$ ) entre o reconhecimento jurídico e a conquista do autorespeito. Dessa forma, o auto-respeito é para a relação jurídica o que a autoconfiança representa para a relação amorosa, estando associado à noção de direito individual, uma vez que possuir direitos individuais significa poder colocar pretensões aceitas. Eles dotam o sujeito individual com a possibilidade de uma atividade legítima, com base na qual ele pode constatar que goza do respeito de todos os demais. É o caráter público que os direitos possuem, porque autorizam seu portador a uma ação perceptível aos parceiros de interação, o que lhes confere a força de possibilitar a constituição do autorespeito; pois, com a atividade facultativa de reclamar direitos, é dado ao indivíduo um meio de expressão simbólica, cuja efetividade social pode demonstrar-lhe reiteradamente que ele encontra reconhecimento universal como pessoa moralmente imputável $^{22}$.

Salienta Honneth que Hegel e Mead distinguiram ainda do amor e da relação jurídica uma outra forma de reconhecimento recíproco. Trata-se da estima social que lhes permite referir-se positivamente a suas propriedades e capacidades concretas ${ }^{23}$.

20 HONNETH, Axel. "Padrões de reconhecimento intersubjetivo: amor, direito, solidariedade" in HONNETH, Axel (trad. Luiz Repa). A Luta por Reconhecimento - A gramática moral dos conflitos sociais. São Paulo: Editora 34, 2003, p. 191.

21 “A comprovação na realidade fenomênica é, no caso do auto-respeito, da maior dificuldade, porque ele só se torna de certo modo uma grandeza perceptível em forma negativa - a saber, quando os sujeitos sofrem de maneira visível com a sua falta". HONNETH, Axel. "Padrões de reconhecimento intersubjetivo: amor, direito, solidariedade" in HONNETH, Axel (trad. Luiz Repa). A Luta por Reconhecimento - A gramática moral dos conflitos sociais. São Paulo: Editora 34, 2003, p. 197.

22 HONNETH, Axel. "Padrões de reconhecimento intersubjetivo: amor, direito, solidariedade" in HONNETH, Axel (trad. Luiz Repa). A Luta por Reconhecimento - A gramática moral dos conflitos sociais. São Paulo: Editora 34, 2003, pp. 195-197.

${ }^{23} \mathrm{Na}$ verdade, Hegel e Mead descreveram a estima social de maneira diversa, mas coincidiram em boa medida na definição de sua função. "Nos escritos de Hegel do período de Jena, havia-se encontrado o 
Buscaram, pois, os autores (Hegel e Mead) caracterizar um tipo, particularmente exigente em termos normativos, de comunidade de valores, em cujo quadro toda forma de reconhecimento por estima está incrustada de modo necessário.

Deste modo, diferentemente do reconhecimento jurídico em sua forma moderna, a estima social se aplica às propriedades particulares que caracterizam os seres humanos em suas diferenças pessoais, por isso, enquanto o direito moderno representa um "medium" de reconhecimento que expressa propriedades universais de sujeitos humanos de maneira diferenciadora, aquela segunda forma de reconhecimento requer um "medium" social que deve expressar as diferenças de propriedades entre sujeitos humanos de maneira universal, isto é, intersubjetivamente vinculante.

A tarefa de mediação é operada, no nível social, por um quadro de orientações simbolicamente articulado, mas sempre aberto e poroso, no qual se formulam os valores e os objetivos éticos, cujo todo constitui a autocompreensão cultural de uma sociedade, que, por sua vez, predetermina os critérios pelos quais se orienta a estima social das pessoas.

Constrói-se, pois, a pressuposição de um contexto de vida social cujos membros constituem uma comunidade de valores mediante a orientação por concepções de objetivos comuns. Contudo, se a estima social é determinada por concepções de objetivos éticos que predominam em uma sociedade, as formas que ela pode assumir são uma grandeza não menos variável historicamente do que as do reconhecimento jurídico. Seu alcance social e a medida de sua simetria dependem então do grau de pluralização do horizonte de valores socialmente definido, tanto quanto do caráter dos ideais de personalidade aí destacados. A estima social assumirá, deste modo, um traço individualizante e criará relações simétricas e ter-se-á a transição dos conceitos de honra às categorias da "reputação" ou "prestígio" social.

A referida transição opera-se com a transposição do modelo de sociedades estamentais e o advento da modernidade.

Em sociedades articuladas em estamentos, a "honra" designa a medida relativa de reputação social que uma pessoa é capaz de adquirir quando consegue cumprir

conceito de 'eticidade' para designar uma semelhante relação de reconhecimento própria da estima mútua; em Mead, por sua vez, pôde se encontrar, para a mesma forma de reconhecimento, não um conceito puramente formal, mas apenas o modelo da divisão cooperativa do trabalho, já institucionalmente concretizado". HONNETH, Axel. "Padrões de reconhecimento intersubjetivo: amor, direito, solidariedade" in HONNETH, Axel (trad. Luiz Repa). A Luta por Reconhecimento - A gramática moral dos conflitos sociais. São Paulo: Editora 34, 2003, p. 198. 
habitualmente expectativas coletivas de comportamento atadas "eticamente" ao status $\operatorname{social}^{24}$.

As formas de reconhecimento associadas a ela assumem o caráter de relações, simétricas por dentro, mas assimétricas por fora, entre os membros estamentais culturalmente tipificados.

Naturalmente, essa ordem de reconhecimento relativamente estável não exclui a possibilidade de que alguns grupos sociais optem pelo caminho especial de uma "counterculture of compensatory respect", a fim de retificar a apreciação do valor de suas propriedades coletivas, bem como permite que os grupos sociais procurem isolar suas próprias características estamentais perante os não-membros, para monopolizar as chances de um alto prestígio social.

Entretanto, com a passagem para a modernidade, a relação de reconhecimento do direito não se desliga apenas, como vimos, da ordem hierárquica da estima social; antes, essa própria ordem é submetida a um processo tenaz e conflituoso de mudança estrutural, visto que se alteram também no cortejo das inovações culturais as condições de validade das finalidades éticas de uma sociedade.

O cosmos social de valores perde tanto seu caráter de objetividade quanto a capacidade de determinar de uma vez por todas uma escala de prestígio social.

O sujeito entra no disputado campo da estima social como uma grandeza biograficamente individuada.

Os princípios de honra alcançam validade universal com o conceito de "dignidade humana". Nos catálogos modernos de direitos fundamentais, é garantida a todos os homens, em igual medida, uma proteção jurídica de sua reputação social e, com isso, tem-se a abertura das concepções axiológicas sociais para distintos modos de auto-realização pessoal; doravante é um certo pluralismo axiológico e o conceito de honra vai se adelgaçando gradativamente, até tornar-se o conceito de prestígio social.

O lugar que o conceito de honra havia ocupado antes no espaço público da sociedade passa então a ser preenchido pouco a pouco pelas categorias de "reputação" ou de "prestígio", com a quais se deve apreender a medida de estima que o indivíduo goza socialmente quanto a suas realizações e a suas capacidades individuais. $\mathrm{O}$

\footnotetext{
24 “[...] o comportamento honroso é apenas a realização suplementar que cada um deve apresentar, a fim de adquirir de fato a medida de reputação social atribuída de modo coletivo a seu estamento em virtude da ordem de valores culturalmente dada". HONNETH, Axel. "Padrões de reconhecimento intersubjetivo: amor, direito, solidariedade" in HONNETH, Axel (trad. Luiz Repa). A Luta por Reconhecimento - A gramática moral dos conflitos sociais. São Paulo: Editora 34, 2003, p. 202.
} 
RFD- Revista da Faculdade de Direito- UERJ, v. 2, n. 21, jan./jun. 2012

"prestígio" ou a "reputação" referem-se somente ao grau de reconhecimento social que o indivíduo merece para sua forma de auto-realização.

Constata Honneth que, nas sociedades modernas, as relações de estima social estão sujeitas a uma luta permanente na qual os diversos grupos procuram elevar, com os meios da força simbólica e em referência às finalidades gerais, o valor das capacidades associadas à sua forma de vida.

Mais do que isso, percebe o autor que as relações da estima social, como já havia visto em Georg Simmel, estão acopladas de forma indireta com os padrões de distribuição de renda. Os confrontos econômicos pertencem constitutivamente a essa forma de luta por reconhecimento.

A estima social assume, portanto, um padrão que confere às formas de reconhecimento associadas a ela o caráter de relações assimétricas entra sujeitos biograficamente individuados.

Contudo, à medida que o indivíduo se sabe membro de um grupo social que está em condição de realizações comuns, cujo valor para a sociedade é reconhecido por todos os demais membros, desenvolve um sentimento de orgulho em relação ao grupo ou de honra coletiva.

Ante o exposto, resta ao autor desenvolver o conceito de "solidariedade", entendido como uma espécie de relação interativa em que os sujeitos tomam interesse reciprocamente por seus modos distintos de vida, já que eles se estimam entre si de maneira simétrica.

O mecanismo da estima simétrica pode explicar até mesmo o fato de a guerra representar amiúde um acontecimento coletivo capaz de fundar relações espontâneas de interesse solidário para além dos limites sociais.

Honneth conclui este ponto de sua teoria esclarecendo que estimar-se simetricamente significa considerar-se reciprocamente à luz de valores que fazem as capacidades e as propriedades do respectivo outro aparecer como significativas para a práxis comum

\subsection{Distribuição como reconhecimento}

Conforme já se mencionou quando do trato da estima social, considera Honneth que até mesmo as injustiças decorrentes de má-distribuição devem ser entendidas como a expressão institucional do desrespeito social, ou melhor dizendo, como injustificadas 
relações de reconhecimento. Segundo o autor, o que aqueles afetados consideram como "injusto" são regras ou medidas institucionalizadas que eles vêem como violadoras daquilo que consideram reclamos bem fundamentados por reconhecimento ${ }^{25}$.

Deste modo, defende o autor uma mudança nas premissas normativas da teoria do reconhecimento com o englobamento de todas as experiências relacionadas à injustiça sob o manto do reconhecimento social, isto é, sob o pálio dos fenômenos da humilhação e do desrespeito. Para Honneth, a separação de tais questões em classes distintas (distribuição e reconhecimento) não se manifesta adequada, pois, além de não exaurir todo o espectro de descontentamentos morais, acaba por sugerir que as experiências de desvantagem "material" possam ser analisadas independentemente dos problemas individuais e de grupos relativos ao reconhecimento social. Assim sendo, considera o autor ser mais plausível que as experiências ligadas à injustiça sejam tratadas como questões concernentes ao reconhecimento ou ao desrespeito, cujas diferenças deverão ser determinadas pelas qualidades ou capacidades que aqueles afetados consideram como injustificadamente não reconhecidas ou não respeitadas ${ }^{26}$.

Neste particular, é alvissareira a reprodução das palavras do referido autor:

[...] a moral experience that can be meaningfully described as one of "disrespect" must be regarded as the motivational basis of all social conflicts: subjects or groups see themselves as disrespected in certain aspects of their capacities or characteristics because they have become convinced that the institucional practice of a legitimate principle of recognition unjustifiably fails to reflect these dispositions. In contrast, the opposition between "economic" and "cultural" conflicts could at most have a secondary significance, since it more precisely designates the respects in which disrespect is experienced ${ }^{27}$.

\section{O contraponto de Nancy Fraser}

Enquanto para Honneth o "reconhecimento" consiste em uma categoria moral e, conseqüentemente, a "distribuição" verifica-se apenas como algo dele derivado, Nancy Fraser nega que a "distribuição" possa ser tratada sob o manto do "reconhecimento".

\footnotetext{
${ }^{25}$ HONNETH, Axel. "Redistributions as Recognition: A Respose to Nancy Fraser" in FRASER, Nancy e HONNETH, Axel (trad. Joel Gob, James Ingram e Christiane Wilke). Redistribution or Recognition? - A political-philosophical exchange. New York e London: Verso, 2003, p. 133.

${ }^{26}$ HONNETH, Axel. "Redistributions as Recognition: A Respose to Nancy Fraser" in FRASER, Nancy e HONNETH, Axel (trad. Joel Gob, James Ingram e Christiane Wilke). Redistribution or Recognition? - A political-philosophical exchange. New York e London: Verso, 2003, p. 134-136.

${ }^{27}$ HONNETH, Axel. "Redistributions as Recognition: A Respose to Nancy Fraser" in FRASER, Nancy e HONNETH, Axel (trad. Joel Gob, James Ingram e Christiane Wilke). Redistribution or Recognition? - A political-philosophical exchange. New York e London: Verso, 2003, p. 157.
} 
Neste particular, a autora propõe a adoção de uma perspectiva dualista ("perspectival dualist") que considere as duas categorias como fundamentais e irredutíveis dimensões da justiça ${ }^{28}$.

Para Fraser, os reclamos por justiça social se dividem hodiernamente em dois tipos. O primeiro consiste no reclamo pela redistribuição como forma de se ter uma melhor distribuição de recursos e riqueza ${ }^{29}$. Já o segundo tipo reside na luta pela implementação de "políticas de reconhecimento" dentro de um contexto em que a assimilação à maioria ou às normas culturais dominantes não mais representa o preço a ser pago por igual respeito ${ }^{30}$.

Assim sendo, a tese geral esposada pela autora ora enfocada está calcada no pressuposto de que atualmente a justiça demanda tanto redistribuição quanto reconhecimento. Isoladamente, elas são insuficientes. Deste modo, do ponto de vista teórico, a tarefa reside em divisar uma concepção bidimensional de justiça que possa acomodar os reclamos de igualdade social e reconhecimento da diferença ${ }^{31}$. Sob o

\footnotetext{
${ }^{28}$ Para Honneth, a adoção de uma perspectiva dual com base na economia e na cultura, por si só, não se sustenta, uma vez que seria igualmente possível abordar tais questões sob outros prismas, como o da moralidade e da lei. Assevera o autor que qualquer perspectiva metodológica remanesce vazia quando não ancorada em bases teórico-sociais, que permitam evidenciar como a reprodução social deve ser entendida nas sociedades capitalistas.Defende, portanto, uma posição que conduz ao que o próprio Honneth resolveu denominar "moral-theoretical monism". HONNETH, Axel. "Redistributions as Recognition: A Respose to Nancy Fraser" in FRASER, Nancy e HONNETH, Axel (trad. Joel Gob, James Ingram e Christiane Wilke). Redistribution or Recognition? - A political-philosophical exchange. New York e London: Verso, 2003, pp. 156-157.
}

${ }^{29}$ A autora exemplifica esta modalidade de reclamo por justiça através da melhor distribuição que se propugna entre Norte e Sul, ricos e pobres e, não tão distante no tempo, entre patrões e empregados. FRASER, Nancy. "Social Justice in the Age of Identity Politics: Redistribution, Recognition, and Participation" in FRASER, Nancy e HONNETH, Axel (trad. Joel Gob, James Ingram e Christiane Wilke). Redistribution or Recognition? - A political-philosophical exchange. New York e London: Verso, 2003, p. 07.

${ }^{30}$ Neste ponto, Fraser evoca entre os exemplos existentes as lutas por reconhecimento envolvendo distintas perspectivas relacionadas a etnia, "raça", gênero e minorias sexuais. FRASER, Nancy. "Social Justice in the Age of Identity Politics: Redistribution, Recognition, and Participation" in FRASER, Nancy e HONNETH, Axel (trad. Joel Gob, James Ingram e Christiane Wilke). Redistribution or Recognition? A political-philosophical exchange. New York e London: Verso, 2003, p. 07.

31 Nancy Fraser busca demonstrar que, apesar da origem filosófica distinta, redistribuição e reconhecimento podem caminhar lado-a-lado. Salienta a autora que "redistribuição" provém da tradição liberal, especialmente da concepção anglo-americana de finais do século XX. Relembra que no anos 70 e 80 filósofos "analíticos" como Jonh Rawls e Ronald Dworkin desenvolveram sofisticadas teorias acerca da justiça distributiva. Tais teorias, na tentativa de sintetizar a ênfase liberal tradicional na liberdade individual com a igualdade decorrente da democracia social, propuseram novas concepções de justiça que poderiam justificar a redistribuição sob o prisma sócio-econômico. Já em relação ao termo "reconhecimento", assevera Fraser que o mesmo provém da filosofia de Hegel, especialmente a fenomenologia da consciência, conforme já se mencionou. Nesta tradição, "reconhecimento" designa um ideal de relações recíprocas entre sujeitos que se vêem como iguais. Esta relação tem sua constituição na subjetividade, isto é, alguém se torna um sujeito individualizável apenas em virtude de capacidade de 
aspecto prático, o objetivo é vislumbrar uma orientação política programática capaz de integrar o melhor da política de redistribuição com o melhor das políticas de reconhecimento ${ }^{32}$.

Dessa forma, é possível, por exemplo, combinar aspectos relativos à exploração de classes com aspectos atinentes a preferências sexuais desprezadas socialmente. É exatamente esse tipo de divisão que Fraser denomina bidimensional ("twodimensional"). Reconhece a autora, entretanto, que nem toda questão concernente à falta de reconhecimento se reflete em má-distribuição e vice-versa. Para melhor elucidar tal questão, cita o exemplo do banqueiro afro-americano de Wall Street, que não consegue um táxi para transportá-lo. Comprova, deste modo, sua teoria no sentido em que uma teoria da justiça deve extrapolar a mera distribuição de bens e direitos para examinar os padrões de valores culturais institucionalizados. Deve ainda perquirir tal teoria se os referidos padrões impedem a paridade de participação na vida social.

Assim sendo, pode-se perceber que o centro normativo da concepção de Fraser reside no que a autora houve por bem denominar paridade de participação ("parity of participation" $)^{33}$. Por essa noção, a justiça requer arranjos sociais que permitam a todos os membros (adultos) da sociedade interagir uns com os outros como pares.

Para tanto, duas condições devem ser satisfeitas. A primeira, identificada como "condição objetiva" de paridade na participação, consiste na necessidade de que a distribuição dos recursos materiais deve dar-se de tal forma que assegure a independência e paridade dos participantes. Caem por terra, portanto, formas e níveis de

reconhecer e ser reconhecido pelo outro. Deste modo, a tese de Hegel implica na constatação de que as relações sociais são prévias à subjetividade. Ao contrário da redistribuição, o reconhecimento é visto como pertencente à esfera da ética. FRASER, Nancy. "Social Justice in the Age of Identity Politics: Redistribution, Recognition, and Participation" in FRASER, Nancy e HONNETH, Axel (trad. Joel Gob, James Ingram e Christiane Wilke). Redistribution or Recognition? - A political-philosophical exchange. New York e London: Verso, 2003, p. 10.

32 Como forma de melhor estabelecer as questões que podem ser enquadradas sob o pálio do reconhecimento, afirma Nancy Fraser que "the paradigm of recognition, likewise, can encompass not only movements aiming to revalue unjustly devalued identities - for example, cultural feminism, black cultural nationalism, and gay identity politics - but also deconstrutive tendencies, such as queer politics, critical 'race' politics, and deconstrutive feminism, which reject the 'essentialism' of traditional identity politics. Thus, it is a broader than identity politics in the conventional sense". FRASER, Nancy. "Social Justice in the Age of Identity Politics: Redistribution, Recognition, and Participation" in FRASER, Nancy e HONNETH, Axel (trad. Joel Gob, James Ingram e Christiane Wilke. Redistribution or Recognition? A political-philosophical exchange. New York e London: Verso, 2003, p. 12.

${ }^{33}$ FRASER, Nancy. "Social Justice in the Age of Identity Politics: Redistribution, Recognition, and Participation" in FRASER, Nancy e HONNETH, Axel (trad. Joel Gob, James Ingram e Christiane Wilke. Redistribution or Recognition? - A political-philosophical exchange. New York e London: Verso, 2003, p. 36. 
dependência econômica e a desigualdade que impede a paridade de participação. Deste modo, estão proscritos os arranjos sociais que institucionalizem a privação, a exploração e as disparidades em riqueza, remuneração e tempo livre. Já a segunda condição requer que os padrões institucionalizados de valores culturais expressem igual respeito por todos os participantes e assegurem iguais oportunidades para o atingimento da estima social. É o que Fraser chama de “condição intersubjetiva” de paridade na participação. Seu intuito reside em sufragar normas que sistematicamente depreciam algumas categorias de pessoas e as qualidades a elas associadas, eliminando os padrões de valores institucionalizados que neguem a elas o "status" de plenos participantes na interação, seja porque as sobrecarrega com excessivos traços distintivos, seja porque falha ao reconhecer suas peculiaridades ${ }^{34}$.

Isto posto, percebe-se que qualquer deliberação só poderá ser considerada verdadeiramente democrática, sob o ponto de vista do reconhecimento, se houver paridade de participação para todos os presentes e possíveis participantes na tomada de decisões. Em troca, isso requer justa distribuição e reconhecimento recíproco. Forma-se, portanto, um inevitável círculo, já que os reclamos por reconhecimento só se justificam sob as condições da paridade de participação, figurando dentre elas o reconhecimento recíproco. Tal círculo, entretanto, não é vicioso, demonstrando apenas o caráter reflexivo da justiça, entendida sob a perspectiva democrática. Sob essa ótica, a justiça

\footnotetext{
${ }^{34}$ Segundo Fraser, a paridade na participação atua em dois cenários: intergrupos e intragrupos. Neste passo, assevera a autora que "what is crucial here is that participatory parity enters the picture at two different levels. First, at the intergroup level, it supplies the standard for assessing the effects of institutionalized patterns of cultural value on the relative standing of minorities vis-à-vis majorities. Thus, one invokes it when considering, for example, whether erstwhile Canadian rules mandating uniform head gear for Mounted Police constituted an unjust majority communitarianism, which effectively closed that occupation to Sikh men. Second, at the intragroup level, participatory parity also serves to asses the internal effects of minority practices for which recognition is claimed. At this level, one invokes it when considering, for example, whether Orthodox Jewish practices of sex segregation in education unjustly marginalize Jewish girls and should therefore be denied public recognition in the form of tax exemption or school subsides.

Taken together, these two levels constitute a double requirement for claims for cultural recognition. Claimants must show, first, that the institutionalization of majority cultural norms denies them participatory parity and, second, that the practices whose recognition they seek do not themselves deny participatory parity - to some group members as well as to nonmembers. For the status model, both requirements are necessary; neither alone is sufficient. Only claims that meet both of them are deserving of public recognition". FRASER, Nancy. "Social Justice in the Age of Identity Politics: Redistribution, Recognition, and Participation" in FRASER, Nancy e HONNETH, Axel (trad. Joel Gob, James Ingram e Christiane Wilke. Redistribution or Recognition? - A political-philosophical exchange. New York e London: Verso, 2003, pp. 40-41.
} 
não pode ser concebida como uma mera imposição, mas sim como algo também produzido pelos seus próprios destinatários ${ }^{35}$.

Cumpre ainda analisar como no bojo do capitalismo globalizado têm se verificado as questões concernentes a classe (sob a perspectiva da distribuição) e "status" (sob a perspectiva do reconhecimento). Neste ponto, uma abordagem adequada deverá levar em conta as diferenças entre as questões concernentes a classe e "status" e as eventuais interações que se verifiquem entre essas categorias. Deve ainda levar em conta a impossibilidade de se reduzir os problemas concernentes a má-distribuição àqueles referentes ao não-reconhecimento e vice-versa.

Insta mencionar que, para Fraser, "status" consiste na ordem intersubjetiva de subordinação derivada de padrões institucionalizados de valores culturais que acabam por fazer com que algumas pessoas não sejam consideradas como parceiros nesta interação de forma plena. Já a idéia de classe reside em uma ordem de subordinação objetiva derivada de arranjos econômicos que negam a alguns autores os meios e recursos que necessitam para uma participação paritária ${ }^{36}$.

É inegável que normas favorecendo brancos, europeus, heterossexuais, homens e cristãos estão institucionalizadas em várias partes do mundo. Elas continuam a impedir uma participação paritária e a definir formas de subordinação com base no "status"37.

\footnotetext{
${ }^{35}$ Para Fraser, a solução reside não em abolir tal círculo, mas em mudar a realidade social. Nas palavras da autora, "the solution, accordingly, is not to abolish the circularity in theory. It is rather to work to abolish it in practice by changing social reality. This requires raising (first-order) claims for redistribution and recognition, to be sure. But it also requires raising second-order or meta-level claims about the conditions in which first-order claims are adjudicated. By arguing publicly that the conditions for genuinely democratic public argument are currently lacking, one express the reflexivity of democratic justice in the process of struggling to realize it practically". FRASER, Nancy. "Social Justice in the Age of Identity Politics: Redistribution, Recognition, and Participation" in FRASER, Nancy e HONNETH, Axel (trad. Joel Gob, James Ingram e Christiane Wilke. Redistribution or Recognition? - A politicalphilosophical exchange. New York e London: Verso, 2003, p. 44.

${ }^{36}$ Indicados os conceitos de classe e "status" para Nancy Fraser, é alvissareira a transcrição de fragmento em que a autora evidencia como as diversas sociedades se apropriam de tais conceitos: "for the fully kingoverned society, one can read off the economic dimension of subordination directly from the cultural; one can infer class directly from status and maldistribution directly from misrecognition. For the fully marketized society, conversely, one can read off the cultural dimension of subordination directly from the economic; one can infer status directly from class and misrecognition directly from maldistribution". FRASER, Nancy. "Social Justice in the Age of Identity Politics: Redistribution, Recognition, and Participation" in FRASER, Nancy e HONNETH, Axel (trad. Joel Gob, James Ingram e Christiane Wilke). Redistribution or Recognition? - A political-philosophical exchange. New York e London: Verso, 2003, p. 53.

${ }^{37}$ Apenas para demonstrar que o referido fenômeno também é apontado por outros autores, manifesta-se salutar a transcrição deste fragmento: "There are now quite sophisticated and sensitive methodologies used in social development which are participatory and designed to involve different groups and include the less visible and vocal (Chambers, 1983; Gibson, 1994; Scoones and Thompson, 1994). Although they have been developed mainly in the context of rural development, their adaptation in urban contexts is
} 
Neste particular, Sassen vislumbra o desenrolar de uma mesma trajetória no que se refere à concentração de renda e fragmentação étnica em Nova Iorque, Tóquio e Londres, sem, por óbvio, descurar das distintas histórias, constituição sócio-econômica e políticas adotadas por cada uma dessas cidades. Afirma a autora que, nessas três cidades, se produziu uma classe "superior" de profissionais (homens) em detrimento de uma classe mal paga de trabalhadores administrativos (em sua maioria composta por mulheres). Além disso, constata a autora o surgimento de uma nova classe trabalhadora de imigrantes, em regra, atuando na economia informal e manufaturas ${ }^{38}$.

Salienta ainda Fraser que existem obstáculos políticos para a paridade de participação. Dentre eles destaca alguns procedimentos de tomada de decisões que sistematicamente marginalizam algumas pessoas, ainda que na ausência de mádistribuição ou não reconhecimento. Esta seria a terceira dimensão de seu pensamento.

Dessa forma, pode-se dizer resumidamente que, a partir da concepção de Fraser, o remédio para a injustiça repousa na remoção de impedimentos para a paridade de participação. A eliminação da má-distribuição passaria pela remoção de impedimentos econômicos através da redistribuição, efetuando-se uma verdadeira reestruturação econômica. Já como forma de se superar o não reconhecimento sugere a autora a remoção de impedimentos culturais, através da desinstitucionalização dos padrões de valores culturais que impedem a paridade de participação e adoção de outros que a

under review (Mitlin and Thompson, 1995; IIED, 1994). In both rural and urban applications, however, participatory appraisal and avaluation can generate conflict and expose vulnerabilities in communities or settlements which, along with existing power relations, are then left behind to be sorted out for better or worse when the research initiators disappear. Although these issues are recognized and critiqued in the literature and in practice, the problem remains that organizations as remote as multilateral agencies, bilateral donors and international NGOs may not always be using participatory tools in participatory ways. They often act without reflection on their relative power, influence and limitations in this area. [...] Debates on difference have underscored how gender as a social relation intersects with other social relations deriving from class, race, ethnicity, age and so on. Such debates, along with those on race, ethnicity and culture, have fed off and fed into post-structuralist, post-colonial and post-modernist scholarship and, for better or worse, have given rise to both a discourse and politics based on identity (Carby, 1982; Hooks, 1984, 1991; Marchmand and Parpat, 1995; Mohenty, 1998, 1992; Moore, 1994; Nicholson, 1990; Parpat, 1993). BEALL, Jo. "Valuing Difference and Working with Diversity" in BEALL, Jo (ed.). A City for All: valuing difference and working with diversity. London e New Jersey: Zed Books, 1997, p. 07.

38 ÖNCÜ, Ayse e WEYLAND, Petra. "Introduction: struggles over lebensraum and social identity in globalizing cities" in ÖNCÜ, Ayse e WEYLAND, Petra. Space, Culture, and Power: new identities in globalizing cities. London e New Jersey: Zed Books, 1997, p. 06. 
promovam. Por fim, para solucionar a "marginalização" ou "exclusão" política deve-se remover os obstáculos via democratização ${ }^{39}$.

Propõe ainda Nancy Fraser a observância de duas estratégias como forma de se remediar a injustiça que reclama redistribuição-reconhecimento: afirmação e transformação ("affirmation" and "transformation").

As estratégias de afirmação possuem dois aspectos: primeiro, quando aplicadas ao não reconhecimento, os remédios afirmativos tendem a reforçar identidades coletivas. Através da valorização da identidade de grupo, eles drasticamente simplificam o autoconhecimento das pessoas, negando a complexidade de suas vidas, a multiplicidade de suas identificações. $O$ aspecto negativo de tais teorias consiste na pressão que geram sobre os indivíduos no sentido de que se adéquam à tipologia de um grupo, desencorajando a dissidência e a experimentação. Reforça-se, deste modo, a supressão de divisões intragrupo e a manutenção de relações de subordinação. Em segundo lugar, os referidos remédios, quando aplicados a questões concernentes a mádistribuição, provocam uma reação violenta de não reconhecimento. No âmbito do Estado de Bem-Estar (Liberal), por exemplo, os programas de assistência social fornecem auxílio aos pobres, deixando intactas, entretanto, as profundas estruturas que geram pobreza. Em casos como esse, as ações afirmativas não apenas falham na solução dos problemas referentes a má-distribuição, como intensificam o não reconhecimento.

Ao revés, as estratégias comprometidas com a transformação passam ao largo de tais dificuldades. Aplicadas ao não reconhecimento, os remédios que desconstroem as

\footnotetext{
${ }^{39}$ FRASER, Nancy. "Social Justice in the Age of Identity Politics: Redistribution, Recognition, and Participation" in FRASER, Nancy e HONNETH, Axel (trad. Joel Gob, James Ingram e Christiane Wilke. Redistribution or Recognition? - A political-philosophical exchange. New York e London: Verso, 2003, p. 73. Insta mencionar que Honneth não compartilha da concepção de Fraser, uma vez que considera que cada princípio atrelado ao reconhecimento apresenta um específico excedente de validade cuja significância é expressa pela constante luta em torno de sua apropriada aplicação e interpretação. Prossegue ainda o autor: "within each sphere, it is always possible to set a moral dialectic of the general and the particular in motion: claims are made for a particular perspective (need, life-situation, contribution) that has not yet found appropriate consideration by appeal to a general recognition principle (love, law, achievement). In order to be up to the task of critique, the theory of justice outlined here can wield the recognition principles' surplus validity against the facticity of their social interpretation. As against the dominant interpretative praxis, it is shown that there are particular, hitherto neglected facts whose moral consideration would require an expansion of the spheres of recognition. To be sure, such critique can only attain a perspective that enables it to distinguished grounded from ungrounded claims by translating the previously outlined general criterion of progress into the semantic of each sphere of recognition. What can count as a rational or legitimate demand emerges from the possibility of understanding the consequences of implementing it as a gain in individuality or inclusion". HONNETH, Axel. "Redistribution as Recognition: A Response to Nancy Fraser" in FRASER, Nancy e HONNETH, Axel (trad. Joel Gob, James Ingram e Christiane Wilke. Redistribution or Recognition? - A politicalphilosophical exchange. New York e London: Verso, 2003, pp. 186-187.
} 
estruturas existentes são, em princípio, considerados deletérios, uma vez que seu objetivo reside na desestabilização de distinções concernentes ao "status". Contudo, quando obtêm sucesso tais remédios desencorajam o conformismo intragrupo que, por vezes, acompanha o multiculturalismo ${ }^{40}$. Aplicadas à má-distribuição tais estratégias manifestam-se solidárias. Focadas no aumento do "bolo" a ser dividido e na reestruturação das condições gerais de trabalho, reduzem as diferenças sem criar classes estigmatizadas. Sob esse prisma, a correção da má-distribuição também permitirá a correção do não reconhecimento.

Deve-se ter em mente que estratégias de transformação são preferíveis em princípio, porém são mais difíceis de efetivação na prática. Daí a indagação formulada por Nancy Fraser: deveriam se sacrificar princípios no altar do realismo?

A autora ainda explora posturas a serem adotadas como forma de se promover a integração. Ela denomina tais posturas de "cross-redressing" e "boundary awareness".

A primeira consiste em utilizar medidas associadas a uma das dimensões da justiça para remediar iniqüidades associadas a outra. Seria o caso de se utilizar medidas concernentes a distribuição para solucionar questões atinentes ao não reconhecimento e medidas associadas ao reconhecimento para equacionar problemas referentes à mádistribuição. Explora-se aqui a inter-relação entre "status" e classe para mitigar simultaneamente ambas as formas de subordinação.

Já a idéia de "boundary awareness" significa a consciência acerca dos impactos decorrentes das diversas reformas nos limites dos grupos. Como já se mencionou, certos esforços para corrigir injustiças servem para diferenciar determinados grupos sociais, enquanto outros servem para "des-diferenciá-los". Por exemplo, esforços pra corrigir a má-distribuição têm por fim precípuo a abolição ou redução de diferenciais econômicos, quer se adote uma ação afirmativa quer se prefira uma abordagem com base na transformação. Contudo, ações afirmativas valorizam a especificidade de determinados $\operatorname{grupos}^{41}$, enquanto estratégias de transformação objetivam a desconstrução de

\footnotetext{
${ }^{40}$ Nas palavras de Fraser, "acknowledging the complexity and multiplicity of identifications, they seek to replace overweening master dichotomies, such as black/white or gay/straight, with a decentered congeries of lower-case differences. When successful, such reforms discourage the en bloc conformism that often accompanies mainstream multiculturalism. And far from promoting separatism or repressive communitarianism, they foster interaction across differences". FRASER, Nancy. "Social Justice in the Age of Identity Politics: Redistribution, Recognition, and Participation" in FRASER, Nancy e HONNETH, Axel (trad. Joel Gob, James Ingram e Christiane Wilke. Redistribution or Recognition? - A political-philosophical exchange. New York e London: Verso, 2003, p. 77.

${ }^{41}$ Neste ponto, afirma Jo Beall que o estabelecimento de diferenças pode transformar-se em um processo de planejamento social. $\mathrm{O}$ aspecto positivo reside na criação de categorias, prioridades e hierarquias; o negativo pode implicar em discriminação ou mesmo em uma espécie de engenharia social, tema já
} 
classificações dicotômicas. Dentro desta segunda perspectiva, com a eliminação das diferenças baseadas no "status", tais estratégias permitiriam a desestabilização dos limites entre grupos.

De fato, o que se pode afirmar é que o desenvolvimento social deve necessariamente ser inclusivo e participativo ${ }^{42}$, reconhecendo as vulnerabilidades e capacidades das pessoas e conferindo a elas apoio para a maximização de suas expectativas $^{43}$. Nesse sentido, um desenvolvimento social sensível às diferenças implicaria em eliminar a exclusão social.

Neste particular, os programas e projetos urbanos devem partir do reconhecimento da existência de uma relação holística entre pobreza, produtividade e ambiente, isto é, entre as componentes econômica, ambiental e social inerentes ao desenvolvimento sustentável urbano. Segundo Caroline Moser, isso inclui intervenções em serviços básicos de educação, saúde, nutrição e planejamento familiar, bem como aumento do acesso a infra-estrutura e habitação ${ }^{44}$, tema que adiante será melhor desenvolvido.

abordado quando do trato das questões concernentes ao não reconhecimento. Neste passo, políticas de desenvolvimento social que têm por objeto grupos específicos podem ser importantes e necessárias na redistribuição de recursos para os mais necessitados. Deve-se, portanto, buscar novas formas de intervenção e interação, isto é, a criação de políticas que reconheçam a existência de diferenças e promovam parcerias e a interação entre diferentes pessoas e segmentos sociais. Por isso, Jo Beall prefere adotar o termo diversidade e não diferença, uma vez que o primeiro seria um conceito mais dinâmico e flexível. Nas palavras da aludida autora, "in the shift from analyses to action, I would argue that it is equally important that planning, management, partnerships and activism interact creatively with diversity, which is a more dynamic and flexible concept than the static one of difference. It is for this reason that the book is sub-titled valuing difference and working with diversity". BEALL, Jo. "Valuing Difference and Working with Diversity" in BEALL, Jo (ed.). A City for All: valuing difference and working with diversity. London e New Jersey: Zed Books, 1997, p. 09.

42 BEALL, Jo. "Valuing Difference and Working with Diversity" in BEALL, Jo (ed.). A City for All: valuing difference and working with diversity. London e New Jersey: Zed Books, 1997, p. 15.

43 "The comparative disadvantage of single women household heads in upgrading and self-build housing projects provides a stark example of how all citizens are not equally prepared for all tasks (Moser, 1997) [...] In order to ensure that women-headed house-holders have the same access to housing as men or women in other household structures, it is something appropriate and useful to train women household heads to be bricklayers, carpenters and joiners so they can have a house and perhaps a job or business in due course. This has been tried successfully in the Caribbean (UNCHS, 1990) where women are active and visible in the labour market but would not necessarily work in other contexts. An alternative approach was adopted by the Bombay-based NGO Sparc in India, wich worked to empower womwn pavementdwellers, through legal literacy and other mens, to demand and lobby for housing themselves". BEALL, Jo. "Valuing Difference and Working with Diversity" in BEALL, Jo (ed.). A City for All: valuing difference and working with diversity. London e New Jersey: Zed Books, 1997, p. 21.

${ }^{44}$ MOSER, Caroline. "Urban Social Policy and Poverty Reduction" in BURGESS, Rod; CARMONA, Marisa e KOLSTEE, Theo (ed.). The Challenge of Sustainable Cities. London e New Jersey: Zed Books, 1997, p. 46. Cumpre ainda salientar que, segundo a autora, faz-se imperioso reconhecer que uma sociedade não igualitária - isto é, uma sociedade calcada em critérios excludentes, determinados 


\section{Reconhecimento e Direito à Moradia: Novas Perspectivas acerca da Regularização Fundiária}

Hodiernamente, encarecem-se, dentro da vertente da habitação, as questões concernentes à moradia e, conseqüientemente, à regularização fundiária.

$\mathrm{O}$ direito à moradia é reconhecido como um direito humano em diversas declarações e tratados internacionais de direitos humanos do qual o Estado Brasileiro é parte, em especial a Declaração Universal de Direitos Humanos de 1948 (artigo XXV, item 1), o Pacto Internacional de Direitos Econômicos, Sociais e Culturais de 1966 (artigo 11), a Convenção Internacional Sobre a Eliminação de Todas as Formas de Discriminação Racial de 1965 (artigo V), a Convenção sobre a Eliminação de Todas as Formas de Discriminação contra a Mulher de 1979 (artigo 14.2, item h), a Convenção sobre os Direitos da Criança de 1989 (artigo 21, item 1), a Declaração sobre Assentamentos Humanos de Vancouver de 1976 (Seção III 98) e Capítulo II (A.3), a Agenda 21 sobre Meio ambiente e Desenvolvimento de 1992 (Capítulo 7, item 6) ${ }^{45}$.

Insta ainda mencionar a Agenda Habitat, surgida a partir da Conferência do Habitat II em Istambul, em que se assinalaram as obrigações dos Estados no sentido de promoverem uma efetiva política habitacional. A referida Agenda preconiza um conjunto de princípios, metas, compromissos e um plano global de ação com o objetivo de orientar os esforços nacionais e internacionais no campo da melhoria dos assentamentos humanos. Neste particular, é ainda alvissareiro mencionar que a Agenda Habitat no Capítulo IV, na parte concernente às estratégias para atingir a meta de

culturalmente com base em renda, sexo, padrões étnicos e raça - é uma sociedade ineficiente, uma vez que várias pessoas ficam alijadas da possibilidade de desenvolver seu completo potencial humano. Conseqüentemente, as políticas sociais devem incentivar a criação de mecanismos que promovam uma melhor distribuição da riqueza. Em suas palavras, "social policy is not only concerned with absolute standards of living in society (absolute poverty) and the instruments, incentives and regulatory framework to affect better distribution. It is also concerned with relative standards of living across the whole society (relative poverty) and the more equitable distribution of wealth. These can be termed equity variables". MOSER, Caroline. "Urban Social Policy and Poverty Reduction" in BURGESS, Rod; CARMONA, Marisa e KOLSTEE, Theo (ed.). The Challenge of Sustainable Cities. London e New Jersey: Zed Books, 1997, p. 50.

45 SAULE JÚNIOR, Nelson. "Formas de Proteção do Direito à Moradia e de Combate aos Despejos Forçados no Brasil" in FERNANDES, Edésio. Direito Urbanístico e Política Urbana no Brasil. Belo Horizonte: Del Rey, 2000, p. 103. 
adequada habitação para todos, exorta em seu artigo 44 a participação de todos os setores da sociedade e não somente dos Governos ${ }^{46}$.

No âmbito do ordenamento pátrio, o direito à moradia somente adentra no rol do artigo $6^{\circ}$ da Constituição da República com a Emenda Constitucional n ${ }^{\circ} 26$ de 14 de fevereiro de 2000. Entretanto, isto não significa que o direito à moradia tenha sido reconhecido como direito constitucional, e fundamental, somente a partir de 2000. Antes mesmo da referida emenda já se poderia extrair da Constituição interpretação a incluí-lo como direito fundamental, considerá-lo sob o abrigo da dignidade da pessoa humana, bem como outros dispositivos do texto constitucional que tratavam da matéria em conjugação com o disposto no artigo $5^{\circ}, \S 2^{\circ}$, da Carta Magna.

No que tange ao princípio da dignidade da pessoa humana, uma de suas funções é o reconhecimento de outros direitos fundamentais que não estejam expressamente previstos como tal na Constituição ${ }^{47}$. Esses são assim chamados direitos materialmente fundamentais. Neste sentido, são os ensinamentos de Ingo Wolfgang Sarlet:

(...) sempre haveria como reconhecer um direito fundamental à moradia como decorrência do princípio da dignidade da pessoa humana (art. $1^{\circ}$, inciso III, da Constituição Federal), já que este reclama, na sua dimensão positiva, a satisfação das necessidades existenciais básicas para uma vida com dignidade, podendo servir até mesmo como fundamento direto e autônomo para o reconhecimento de direito fundamentais não expressamente positivados, mas inequivocamente destinados à proteção da dignidade. ${ }^{48}$

Com efeito, não há como não se reconhecer que sem moradia adequada é impossível viver com dignidade. A moradia é um direito através do qual outros se realizam, como por exemplo, o direito à privacidade, ao bem-estar, à saúde etc,

\footnotetext{
${ }^{46}$ Preleciona o aludido dispositivo que "[...] a provisão de moradia adequada para todos requer ações não somente dos Governos, mas de todos os setores da sociedade, incluindo o setor privado, as organizações não governamentais, comunidades e autoridades locais, bem como pelos parceiros, organizações, e entidades da comunidade internacional".

${ }^{47}$ Daniel Sarmento, em sua obra intitulada Ponderação de interesses na Constituição Federal, destaca as diversas funções que o princípio da dignidade da pessoa humana desempenha, dentre eles a de prestar ao reconhecimento de direitos fundamentais atípicos. SARMENTO, Daniel. A ponderação de interesses na Constituição Federal. Rio de Janeiro: Editora Lumen Juris, 2003.

48 SARLET, Ingo Wolfgang. O direito fundamental à moradia na Constituição: algumas anotações a respeito de seu contexto, conteúdo e possível eficácia in SAMPAIO, José Adércio Leite (org). Crises e desafios da Constituição. Belo Horizonte: Del Rey, 2004, p. 428.
} 
compondo o que se denomina de mínimo existencial ${ }^{49}$. Mais uma vez é alvissareira a transcrição das lições de Ingo Wolfgang Sarlet:

Com efeito, sem um lugar adequado para proteger-se a si próprio e a sua família contra as intempéries, sem um local para gozar de sua intimidade e privacidade, enfim, de um espaço essencial para viver com um mínimo de saúde e bem estar, certamente a pessoa não terá assegurada sua dignidade, aliás, por vezes não terá sequer assegurado o direito à própria existência física, e portanto, o seu direito à vida. ${ }^{50}$

Cumpre ainda salientar, que os documentos internacionais, a que se aludiu anteriormente, caso sejam submetidos ao procedimento constante no $\S 3^{\circ}$, do artigo $5^{\circ}$, da Constituição (acrescentado pela Emenda Constitucional n ${ }^{\circ} 45$ de 2004), adquirirão status de norma constitucional expressa.

Dessa forma, não se pode olvidar da importância que o direito à moradia adquire como integrante da categoria dos direitos econômicos, sociais e culturais, bem como se encontra fora de questão que para ter eficácia jurídica e social pressupõe, conforme já se mencionou, a ação positiva do Estado, através de execução de políticas públicas, no caso em especial da promoção da política urbana e habitacional ${ }^{51}$. Tal obrigação acaba, portanto, por se desdobrar em dois aspectos. O primeiro reside na regressividade do direito à moradia, isto é, consiste em obstar ações que dificulte ou impossibilite o exercício do direito à moradia. Já o segundo desvela-se como a intervenção e regulamentação das atividades do setor privado referente à política habitacional ${ }^{52}$. Exemplifica Nelson Saule Júnior com a

\footnotetext{
${ }^{49}$ LIMA, Thais dos Santos. Da usucapião urbana coletiva (art. 10, da Lei ${ }^{\circ}$ 10.257/2001): uma análise sob a ótica do Direito Constitucional. Monografia (graduação em Direito) - Universidade do Estado do Rio de Janeiro, Centro de Ciências Sociais, Faculdade de Direito, pp. 55-56.

${ }^{50}$ SARLET, Ingo Wolfgang. O direito fundamental à moradia na Constituição: algumas anotações a respeito de seu contexto, conteúdo e possível eficácia in SAMPAIO, José Adércio Leite (org). Crises e desafios da Constituição. Belo Horizonte: Del Rey, 2004, p. 432.

${ }^{51}$ Neste particular, afirma Nelson Saule Junior que "o Estado brasileiro no que diz respeito à política habitacional tem a obrigação de instituir organismos, constituir uma legislação, programas, planos de ação e instrumentos de modo a garantir esse direito para os seus cidadãos. Cabe esclarecer que essa obrigação não significa que o Estado brasileiro deve prover uma moradia (uma casa) para cada cidadão". SAULE JÚNIOR, Nelson. "Formas de Proteção do Direito à Moradia e de Combate aos Despejos Forçados no Brasil" in FERNANDES, Edésio. Direito Urbanístico e Política Urbana no Brasil. Belo Horizonte: Del Rey, 2000, p. 105.
}

${ }^{52}$ O Município, por exemplo, para desenvolver a política habitacional municipal, deve instituir o plano diretor como o instrumento básico desta política, de modo que sejam estabelecidos as diretrizes e os instrumentos sobre o uso e ocupação do solo urbano, formas de cooperação entre o setor público e o privado, e disciplinar os critérios para o uso social da propriedade urbana. O Município também pode adotar como instrumentos leis específicas de habitação de interesse social e de planos de urbanização para assentamentos em condições precárias de habitabilidade, operações de interesse social, transferência do direito de construir, solo criado, zonas especiais de interesse social e a concessão de direito real utilizado 
regulamentação do uso e acesso a propriedade imobiliária, em especial a urbana, de modo que atenda sua função social, e regulamentar o mercado de terra, dispor sobre sistemas de financiamento da habitação de interesse social, regulamentar e dispor sobre o uso do solo urbano, sobre o direito de construir, sobre instrumentos tributários e sobre os regimes de locação, de concessão de uso para fins de moradia ${ }^{53}$.

Entretanto, é acurado salientar que, mesmo para que o Estado possa atuar, verifica-se imperioso o reconhecimento daqueles que serão beneficiados pela sua atuação como titulares de direitos, isto é, como membros de igual valor da coletividade política $^{54}$. Como se pode inferir da teoria de Honneth, reclama-se aqui que todos, inclusive aqueles pertencentes a classes ou possuidores de "status" considerados "inferiores", vejam resguardado seu direito à moradia e, para tento, é imprescindível o reconhecimento como pessoa de direito. Essa idéia deve ser aplicada a todo sujeito na mesma medida ${ }^{55}$ e, neste ponto, aparta-se, conforme já se mencionou, do grau de estima social, gerando dois aspectos semânticos do termo "respeito". "[...] No primeiro caso se trata daquela propriedade universal que faz dele uma pessoa; no segundo caso, pelo

para fins de regularização fundiária. Cumpre ainda mencionar que as mudanças na ordem urbana passam, sobretudo, pelo estabelecimento de leis e instrumentos jurídicos que permitam o reconhecimento da legalidade dos assentamentos informais consolidados (favelas, cortiços, loteamentos populares nas periferias urbanas) como forma de impedir os despejos forçados contra a população que vive nos assentamentos informais; reconhecer o direito de todo aquele que vive em uma dessas áreas de ter um título formal de área urbana, bem como facultar-lhe acesso a uma moradia digna com infra-estrutura urbana e prestação de serviços públicos; e, por fim, tornar o Poder Público um partícipe mais efetivo, gerando-lhe a obrigação de melhoria das condições urbanas e ambientais.

53 SAULE JÚNIOR, Nelson. "Formas de Proteção do Direito à Moradia e de Combate aos Despejos Forçados no Brasil" in FERNANDES, Edésio. Direito Urbanístico e Política Urbana no Brasil. Belo Horizonte: Del Rey, 2000, p. 106.

\footnotetext{
${ }^{54}$ Lembre-se que, conforme já se salientou, Honneth, ao tratar de tal tema, cita a tese de Marshall acerca de como o teor de reconhecimento do direito se ampliou passo a passo. Dela extrai que, embora Marshall adote um tripartição das pretensões jurídicas a partir de um viés histórico (cuja versão mais simplória, conforme já se mencionou, preleciona que a constituição dos direitos liberais de liberdade deu-se no século XVIII, o estabelecimento dos direitos políticos de participação, no XIX, e finalmente a criação de direitos sociais de bem-estar, no XX), "é importante para nossos fins somente a demonstração de que a imposição de cada nova classe de direitos fundamentais foi sempre forçada historicamente com argumentos referidos de maneira implícita à exigência de ser membro com igual valor da coletividade política". HONNETH, Axel. "Padrões de reconhecimento intersubjetivo: amor, direito, solidariedade" in HONNETH, Axel (trad. Luiz Repa). A Luta por Reconhecimento - A gramática moral dos conflitos sociais. São Paulo: Editora 34, 2003, p. 191.
}

${ }^{55}$ Afinal, conforme já se mencionou, quando da análise da influência de Mead sobre a teoria de Honneth, todo sujeito humano pode ser considerado portador/titular de alguns direitos, quando reconhecido socialmente como membro de uma coletividade. HONNETH, Axel. "Padrões de reconhecimento intersubjetivo: amor, direito, solidariedade" in HONNETH, Axel (trad. Luiz Repa). A Luta por Reconhecimento - A gramática moral dos conflitos sociais. São Paulo: Editora 34, 2003, p. 180. 
contrário, trata-se das propriedades particulares que o caracterizam, diferentemente de outras pessoas 56 ,

Neste ponto, insta salientar que

a definição das propriedades que caracterizam o ser humano constitutivamente como pessoa depende das assunções de fundo acerca dos pressupostos subjetivos que capacitam para a participação numa formação racional da vontade: quanto mais exigente é a maneira pela qual se pensa um semelhante procedimento, tanto mais abrangentes devem ser as propriedades que, tomadas em conjunto, constituem a imputabilidade moral de um sujeito 57 .

Deste modo, em virtude de uma constante luta por reconhecimento, devem ser sempre adicionados novos pressupostos para a participação na formação racional da vontade de forma a possibilitar uma ampliação das normas jurídicas e incorporar a dimensão da igualdade material de chances.

Caso se adote a teoria de Fraser, talvez este seja um dos principais cenários para que se aplique a estratégia de "cross-redressing" como forma de se explorar a interrelação entre "status" e classe para mitigar ambas as formas de subordinação que caracterizam, ou melhor, impõem-se à população de baixa renda que ocupa as áreas favelizadas ou vêem denegado seu direito à moradia de forma plena.

Neste particular, as normas e políticas de regularização fundiária, que objetivem o asseguramento e ampliação do direito à moradia, ocupam posição de destaque. Contudo, antes propriamente de justificar tal proeminência, faz-se necessário delimitar as ações pressupostas por um plano efetivo de regularização fundiária, abandonando, conseqüentemente, a perspectiva de que as mesmas resumem-se à regularização jurídica dos lotes em nome dos moradores. Assim sendo, embora seja essencial que o Poder Público, ao intervir em um assentamento, garanta, juridicamente, a continuidade do exercício do direito de moradia à população, através da utilização dos instrumentos da usucapião urbana e da concessão do direito real de uso (conforme seja a área privada ou pública, respectivamente), deve garantir que injustiças não se produzam.

Nesse sentido, é elucidadora a lição de Bethânia de Moraes Alfonsin:

Para o Poder Público, no entanto, há uma inconveniência ética ao se garantir apenas a titulação do lote, pois muitas vezes a forma como a área

\footnotetext{
56 HONNETH, Axel. "Padrões de reconhecimento intersubjetivo: amor, direito, solidariedade" in HONNETH, Axel (trad. Luiz Repa). A Luta por Reconhecimento - A gramática moral dos conflitos sociais. São Paulo: Editora 34, 2003, p. 187.

57 HONNETH, Axel. "Padrões de reconhecimento intersubjetivo: amor, direito, solidariedade" in HONNETH, Axel (trad. Luiz Repa). A Luta por Reconhecimento - A gramática moral dos conflitos sociais. São Paulo: Editora 34, 2003, p. 188.
} 
foi ocupada consagra injustiças. Há casos de assentamentos em que alguns lotes têm tamanho bastante superior à média dos demais lotes e, simultaneamente, há lotes encravados, sem acesso para o logradouro público, por exemplo. Em outros casos, as favelas não são dotadas da menor infra-estrutura, não sendo nem ao menos servidas por água potável. Como política conduzida pela Administração Pública não se deveria esperar de uma intervenção de regularização fundiária uma correção dessas distorções atinentes à configuração e à carência de infra-estrutura do assentamento $?^{58}$

Entretanto, não se pode perder de vista que a regularização física do assentamento reside em um primeiro passo relevante para a realização de uma plena regularização fundiária. As favelas - que se caracterizam pela ocupação desordenada do solo, carência de infra-estrutura e presença de habitações precariamente construídas demandam a melhoria das condições de habitabilidade. Dessa forma, um projeto de urbanização a ser implementado nessas áreas, poderá e deverá incluir mecanismos que possibilitem a elevação da qualidade de vida das populações residentes, tais como:

- o redesenho do sistema de circulação interna do assentamento, com alargamento de becos e abertura de novas vias de acesso;

- criação de espaços públicos internos, que possam ser utilizados para fins de lazer às comunidades;

- o redesenho de lotes de tamanho muito superior à média dos lotes, aproveitando o terreno excedente para fins públicos;

- a relocalização de algumas casas locadas em espaços estratégicos para o projeto de urbanização;

- a reconstrução de algumas casas, justamente aquelas que estiverem mais deterioradas;

- a preservação de alguns equipamentos urbanos como creches existentes;

- a definição de espaços em que veículos como caminhão de bombeiros e ambulâncias possam penetrar no sistema espacial do assentamento ${ }^{59}$.

Insta mencionar que a adoção das referidas medidas deve ser acompanhada do asseguramento da titulação dos lotes em nome dos moradores, pois a falta de regularização jurídica pode gerar futuros despejos e/ou desperdício de dinheiro público.

Com a adoção de tais medidas, faz-se com que áreas ocupadas em desconformidade com a legislação urbanística sejam novamente recepcionadas pela legislação. Contudo, tal readequação não pode implicar no acobertamento de uma postura excludente, isto é, não pode configurar procedimento que objetive constituir mais um obstáculo à permanência da população favelada naquelas áreas urbanas que os

\footnotetext{
58 ALFONSIN, Bethânia de Moraes. "Políticas de Regularização Fundiária: Justificação, Impactos e Sustentabilidade" in FERNANDES, Edésio. Direito Urbanístico e Política Urbana no Brasil. Belo Horizonte: Del Rey, 2000, p. 212.

59 ALFONSIN, Bethânia de Moraes. "Políticas de Regularização Fundiária: Justificação, Impactos e Sustentabilidade" in FERNANDES, Edésio. Direito Urbanístico e Política Urbana no Brasil. Belo Horizonte: Del Rey, 2000, pp. 212-213.
} 
planejadores consideravam "nobres" demais para serem ocupadas por população de baixa renda ${ }^{60}$. Para tanto, deve-se adotar uma abordagem que permita enfatizar a recuperação urbana da favela como forma de atender ao regime urbanístico originalmente previsto no plano, bem como possibilite a adaptação da legislação e do regime urbano à especificidade das referidas áreas ${ }^{61}$.

Neste particular, a definição cunhada por Bethânia Alfonsin para a expressão regularização fundiária merece ser reproduzida:

Regularização fundiária é o processo de intervenção pública, sob os aspectos jurídico, físico e social, que objetiva legalizar a permanência de populações moradoras de áreas urbanas ocupadas em desconformidade com a lei para fins de habitação, implicando acessoriamente melhorias no ambiente urbano do assentamento, no resgate da cidadania e da qualidade de vida da população beneficiária ${ }^{62}$.

Percebe-se, pois, que apenas através de um trabalho jurídico, urbanístico, físico e social será possível reduzir o atual quadro de agravamento da degradação ambiental e das desigualdades sociais e territoriais inerentes às cidades brasileiras, devido à existência de duas cidades em um mesmo território: a cidade legal, onde vivem os

\footnotetext{
${ }^{60}$ Apenas para se demonstrar os cuidados que se deve ter quando da adoção de uma perspectiva crítca, é acurada a transcrição do seguinte fragmento: "by contrast, a critique of society that attempts to bracket locally prevalent value horizons or to transcend them by referring to external standards necessarily assumes a perspective that is too distanced, which is why this kind of critique is always in danger of claiming to represent elite, specialist knowledge that is capable of being easily misused for purposes of manipulation". HONNETH, Axel. "The Possibility of a Disclosing Critique of Society: The Dialectic of Enligtenment in Light of Current Debates in Social Criticism" in HONNETH, Axel. Disrespect: The Normative Foundations of Critical Theory. Cambridge: Polity Press, 2007, pp. 51-52.

${ }^{61}$ Nas palavras de Bethânia de Moraes Alfonsin, "o primeiro enfoque é mais conservador de matriz positivista. Essa visão tem perdido espaço no Brasil para a segunda ênfase, na qual se reconhece a especificidade do território de favela, a impossibilidade de atendimento do regime urbanístico original e a necessidade de propor novos padrões urbanísticos coerentes com o padrão de ocupação do próprio assentamento.

Essa segunda visão da regularização urbanística consiste em um aspecto central da regularização fundiária. A irregularidade urbanística é, na prática, um dos maiores entraves à regularização de assentamentos informais. A afetação e/ou gravame de áreas com usos institucionais e equipamentos urbanos como praças, escolas e leitos de rua, em locais que, muitas vezes, já se constituíam em territórios ocupados por favela, não foi manobra rara na história do planejamento urbano brasileiro. Freqüentemente foi procedimento intencional que objetivava constituir mais um obstáculo à permanência da população favelada naquelas áreas urbanas que os planejadores consideravam 'nobres' demais para serem ocupadas por população de baixa renda.

Quando se tem clareza da necessidade e vontade política de implementar programas de regularização fundiária, essas históricas irresponsabilidades administrativas precisam ser enfrentadas [...]". ALFONSIN, Bethânia de Moraes. "Políticas de Regularização Fundiária: Justificação, Impactos e Sustentabilidade" in FERNANDES, Edésio. Direito Urbanístico e Política Urbana no Brasil. Belo Horizonte: Del Rey, 2000, pp. 214-215.
}

${ }^{62}$ ALFONSIN, Bethânia de Moraes. Direito à Moradia: instrumentos e experiências de regularização fundiária nas cidades brasileiras. Rio de Janeiro: FASE/IPPUR, Observatório de Políticas Urbanas, 1997, p. 24. 
incluídos e a cidade informal ou real, onde vive a maioria da população, composta pelos excluídos e marginalizados ${ }^{63}$. Devem, portanto, os programas de regularização fundiária ser revestidos de um aspecto pluridimensional: a legalização da posse exercida com fins de moradia, a melhoria do ambiente urbano do assentamento e realização de um resgate ético que a cidade tem que fazer, "através das políticas urbanas que implementa, da condição cidadã das pessoas que moravam de forma segregada social e espacialmente, portanto apartadas do conjunto de bens materiais e simbólicos oferecidos/produzidos pela urbe ${ }^{64,}$.

A partir de tais pressupostos, torna-se mais evidente a aludida relevância das normas e políticas de regularização fundiária, como mecanismos de promoção do direito à moradia, no âmbito da luta pelo reconhecimento, uma vez que "um sujeito é respeitado se encontrar reconhecimento jurídico não só na capacidade abstrata de poder orientar-se por normas morais, mas também na propriedade concreta de merecer o nível de vida necessário para isso ${ }^{65}$ ". Objetiva-se, em outras palavras, conferir a todos os implicados, inclusive aqueles grupos considerados desfavorecidos, a condição necessária para a participação igual num acordo racional e, para isso, é imprescindível assegurar-se juridicamente a participação no processo público de formação da vontade, bem como conferir a todos condições de agir autonomamente através do asseguramento de uma medida mínima de formação cultural e de segurança econômica ${ }^{66}$.

\footnotetext{
${ }^{63}$ Vários fatores podem influir para que se verifique o referido processo de marginalização. Dentre eles, destaca Jo Bell, "the renovation of run-down inner city areas for occupation by high-income groups means that the original inhabitants, often elderly people or ethnic minorities who have lived in these areas all their lives, are gradually pushed out by rising incomes". BEALL, Jo. "Valuing Difference and Working with Diversity" in BEALL, Jo (ed.). A City for All: valuing difference and working with diversity. London e New Jersey: Zed Books, 1997, p. 18.

${ }^{64}$ ALFONSIN, Bethânia de Moraes. "Políticas de Regularização Fundiária: Justificação, Impactos e Sustentabilidade" in FERNANDES, Edésio. Direito Urbanístico e Política Urbana no Brasil. Belo Horizonte: Del Rey, 2000, p. 217.

${ }^{65}$ HONNETH, Axel. "Padrões de reconhecimento intersubjetivo: amor, direito, solidariedade" in HONNETH, Axel (trad. Luiz Repa). A Luta por Reconhecimento - A gramática moral dos conflitos sociais. São Paulo: Editora 34, 2003, p. 193.

${ }^{66}$ Deve-se aqui relembrar que viver sem direitos significa para o membro individual da sociedade não possuir chance alguma de constituir um auto-respeito. Na concepção de Mead, ora reproduzida por Honneth, possuir direitos significa "poder colocar pretensões aceitas, eles dotam o sujeito individual com a possibilidade de uma atividade legítima, com base na qual ele pode constatar que goza do respeito de todos os demais. É o caráter público que os direitos possuem, porque autorizam seu portador a uma ação perceptível aos parceiros de interação, o que lhes confere a força de possibilitar a constituição do autorespeito; pois, com a atividade facultativa de reclamar direitos, é dado ao indivíduo um meio de expressão simbólica, cuja efetividade social pode demonstrar-lhe reiteradamente que ele encontra reconhecimento universal como pessoa moralmente imputável". HONNETH, Axel. "Padrões de reconhecimento intersubjetivo: amor, direito, solidariedade" in HONNETH, Axel (trad. Luiz Repa). A Luta por Reconhecimento - A gramática moral dos conflitos sociais. São Paulo: Editora 34, 2003, p. 197.
} 


\section{Conclusão}

A "luta pelo reconhecimento", tal como concebida por Hegel, encontrou um novo horizonte em virtude da globalização decorrente da adoção do modelo capitalista que acabou permitindo e acelerando contatos transculturais, pluralizando horizontes valorativos e politizando identidades e diferenças.

Constata-se que os conflitos decorrentes de divergências sobre religião, nacionalidade e gênero estão agora tão imbricados que tornam as questões relativas ao reconhecimento impossíveis de serem ignoradas. Por outro lado, iniqüidades no âmbito econômico crescem significativamente, já que forças neoliberais promovem um processo de globalização sob o prisma corporativo e enfraquecem as estruturas de governo que anteriormente permitiam uma melhor redistribuição dos recursos.

Neste particular, as metrópoles urbanas, dentro de um perímetro relativamente estreito, congregaram a diversidade e a variedade das culturas especiais; pelo menos em quantidades apreciáveis, todas as raças e culturas podem ali ser encontradas, juntamente com suas línguas, seus modos, seus costumes, suas cozinhas típicas; ali os representantes da humanidade se encontraram pela primeira vez frente a frente. Tem-se ali reunidas a complexidade e a variedade do mundo como um todo.

Conforme se buscou demonstrar, é nesse contexto que surgem as concepções de Axel Honneth e Nancy Fraser sobre justiça e, conseqüentemente, sobre reconhecimento e redistribuição.

A diferença entre os autores, conforme já se mencionou, reside, resumidamente, no fato de que - enquanto Fraser desenvolve uma perspectiva dualista ("perspectival dualist"), calcada na idéia de que a justiça engloba tanto as perspectivas do reconhecimento quanto da distribuição, sem ser possível reduzir uma à outra - Honneth desenvolve um aporte alternativo. Ele propõe um "monismo normativo" ("normative monism”). Analisando o reconhecimento como um conceito diferenciado, que engloba o "reconhecimento de direitos", o apreço calcado em características culturais e as questões concernentes ao amor, busca o referido autor desenvolver um aporte que também abranja as problemáticas referentes à redistribuição. 
Buscou-se aqui, portanto, a partir das aludidas concepções, analisar questão que tem adquirido grande relevo hodiernamente, principalmente em virtude do adensamento dos grandes centros urbanos: o reconhecimento e efetivação do direito à moradia e a realização de uma efetiva regularização fundiária. Para tanto, verifica-se imperioso o reconhecimento daqueles ocupantes de áreas irregulares e desprovidos de uma moradia adequada como sujeitos da relação, conferindo-lhes visibilidade no espaço social, uma vez que

[...] para corrigir as deficiências da nossa [...] civilização, teremos de construir um sistema de controle de centros múltiplos, com desenvolvimento ou moralidade, inteligência e respeito próprio, suficientes para permitir que se detenham os processos automáticos mecânicos, burocráticos, organizacionais - em qualquer ponto onde a vida humana esteja em perigo ou a personalidade humana seja ameaçada de perda dos valores alternativos ${ }^{67}$.

$\mathrm{O}$ direito à moradia, apresenta-se, portanto, sob um duplo aspecto. $\mathrm{O}$ primeiro de defesa e o segundo como intervenção/regulamentação das atividades do setor privado referente à política habitacional por parte do Estado. Nesta seara, Ingo Wolfgang Sarlet, seguindo a linha de pensamento de Robert Alexy e Gomes Canotilho, admite ainda a existência de um aspecto prestacional:

Com base no exposto, verifica-se que o problema apenas poderá se equacionado à luz das circunstâncias do caso concreto e do direito fundamental específico em pauta, sendo indispensável a ponderação (hierarquização) dos bens e valores em conflito. Assim, em todas as situações em que o argumento da reserva de competência do legislador (assim como a separação de poderes e as demais objeções habituais aos direitos sociais a prestações como direitos subjetivos) implicar grave agressão (ou mesmo o sacrifício) do valor maior da vida e da dignidade da pessoa humana, ou nas hipóteses em que, da análise dos bens constitucionais colidentes, resultar a prevalência do direito social prestacional, poder-se-á sustentar, na esteira de Alexy e de Gomes Canotilho, que, na esfera de um padrão mínimo existencial, haverá, em princípio, a possibilidade de reconhecer um direito subjetivo definitivo a prestações. Admitindo-se, onde tal mínimo for ultrapassado, tão-somente um direito subjetivo "prima facie", já que - nesta seara - não há como resolver a problemática em termos de um lógica do tudo ou nada. ${ }^{68}$

Dessa forma, pode-se concluir que independentemente da posição que se adote, isto é, independentemente da adoção da concepção esposada por Honneth ou daquela defendida por Fraser, qualquer deliberação só poderá ser considerada verdadeiramente

${ }^{67}$ MUMFORD, Lewis (trad. Neil R. da Silva). A Cidade na História: suas origens, transformações e perspectivas. 4 ed. São Paulo: Martins Fontes, 1998, p. 598.

${ }^{68}$ SARLET, Ingo Wolfgang. O direito fundamental à moradia na Constituição: algumas anotações a respeito de seu contexto, conteúdo e possível eficácia in SAMPAIO, José Adércio Leite (org). Crises e desafios da Constituição. Belo Horizonte: Del Rey, 2004, p. 461. 
democrática, sob o ponto de vista do reconhecimento, se houver paridade de participação para todos os presentes e possíveis participantes na tomada de decisões, somente dessa forma será possível realmente se falar em justiça. Para corroborar essa assertiva, é oportuna a transcrição do seguinte extrato:

\begin{abstract}
Not least as a result of the temporal coincidence of the fall of the Soviet empire and the Western debate on communitarianism, efforts to elucidate the normative foundations of democracy have been increasing worldwide in recent years. However, wherever an attempt was made to link up with the tradition of radical democracy - as demarcated from frontation between republicanism and proceduralism. Today, these key terms ordinarily designate two normative models of democracy whose common goal it is to give democratic will-formation a greater role than in political liberalism. Instead of limiting the participatory activity of citizens to the function of periodically legitimating the state's exercise of power, their activity is to be a permanent matter embodied in the democratic public sphere and should be understood as the source of all political decisionmaking processes ${ }^{69}$.
\end{abstract}

Espera-se, portanto, que as grandes cidades preparem a espécie humana para as associações e unificações maiores, que a moderna conquista do tempo e do espaço tornaram prováveis, senão inevitáveis. Talvez a partir desse momento poder-se-á falar na adoção efetiva de uma estratégia de transformação nos moldes propostos por Fraser: com redução das diferenças sem criar classes estigmatizadas.

\title{
6. Referências bibliográficas
}

ALFONSIN, Bethânia de Moraes. Direito à Moradia: instrumentos e experiências de regularização fundiária nas cidades brasileiras. Rio de Janeiro: FASE/IPPUR, Observatório de Políticas Urbanas, 1997.

BEALL, Jo (ed.). A City for All: valuing difference and working with diversity. London e New Jersey: Zed Books, 1997.

BURGESS, Rod; CARMONA, Marisa e KOLSTEE, Theo (ed.). The Challenge of Sustainable Cities. London e New Jersey: Zed Books, 1997.

FERNANDES, Edésio. Direito Urbanístico e Política Urbana no Brasil. Belo Horizonte: Del Rey, 2000.

FRASER, Nancy e HONNETH, Axel (trad. Joel Gob, James Ingram e Christiane Wilke). Redistribution or Recognition? - A political-philosophical exchange. New York e London: Verso, 2003.

\footnotetext{
${ }^{69}$ HONNETH, Axel. "Democracy as Reflexive Cooperation: John Dewey and the Theory of Democracy Today" in HONNETH, Axel. Disrespect: The Normative Foundations of Critical Theory. Cambridge: Polity Press, 2007, p. 218.
} 
HONNETH, Axel (trad. Luiz Repa). A Luta por Reconhecimento - A gramática moral dos conflitos sociais. São Paulo: Editora 34, 2003.

HONNETH, Axel. Disrespect: The Normative Foundations of Critical Theory. Cambridge: Polity Press, 2007.

LIMA, Thais dos Santos. Da usucapião urbana coletiva (art. 10, da Lei ${ }^{o}$ 10.257/2001): uma análise sob a ótica do Direito Constitucional. Monografia (graduação em Direito) Universidade do Estado do Rio de Janeiro, Centro de Ciências Sociais, Faculdade de Direito.

MUMFORD, Lewis (trad. Neil R. da Silva). A Cidade na História: suas origens, transformações e perspectivas. 4 ed. São Paulo: Martins Fontes, 1998.

ÖNCÜ, Ayse e WEYLAND, Petra. Space, Culture, and Power: new identities in globalizing cities. London e New Jersey: Zed Books, 1997.

PESSOA, Álvaro (coord.). Direito do Urbanismo: uma visão sócio-jurídica. Rio de Janeiro: Livros Técnicos e Científicos: Instituto Brasileiro de Administração Municipal, 1981.

SARMENTO, Daniel. A ponderação de interesses na Constituição Federal. Rio de Janeiro: Editora Lumen Juris, 2003.

SAMPAIO, José Adércio Leite (org). Crises e desafios da Constituição. Belo Horizonte: Del Rey, 2004. 